\title{
PRODUÇÃO DE ANTICORPOS MONOCLONAIS CONTRA O VÍRUS DO MOSAICO DO TOMATEIRO (TOMV)
}

\author{
KEILA MARIA RONCATO DUARTE \\ Engenheira Agrônoma
}

Orientador: Prof. Dr. Flavio Cesar Almeida Tavares

\begin{abstract}
Dissertação apresentada à Escola Superior de Agricultura "Luiz de Queiroz", da Universidade de São Paulo, para obtenção do título de Mestre em Agronomia, Área de concentração: Microbiologia Agrícola.
\end{abstract}

PIRACICABA

Estado de São Paulo - Brasil

Agosto- 1995 


\section{PRODUÇÃO DE ANTICORPOS MONOCLONAIS CONTRA O VÍRUS DO MOSAICO DO TOMATEIRO (ToMV)}

KEILA MARIA RONCATO DUARTE

Aprovada em: 27/10/1995

Comissão Julgadora:

Prof. Dr. Flavio Cesar de Almeida Tavares

ESALQ/USP

Profa. Dra. Elke Jurandy Bran Nogueira Cardoso

ESALQ/USP

Dr. Jean-Luc Gesztesi

UNIFESP

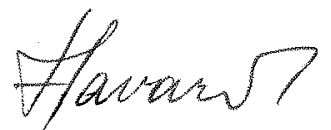

Prof. Dr. Flavio Cesar Almeida Tavares

Orientador 
AOS MEUS PAIS,

DEDICO 


\section{AGRADECIMENTOS}

Agradeço a todos aqueles que contribuíram para a realização deste trabalho, especialmente:

- Prof. Dr. Flavio Cesar Almeida Tavares, pela orientação;

- Prof. Dr. José Daniel Lopes da Biologia Celular - UNIFESP, meu co-orientador, pela confiança e pelo enorme carinho;

- Luiz Humberto Gomes, por estar sempre a meu lado;

- Dr. Jean-Luc Gesztesi, pela paciência e pelos ensinamentos;

- Prof. Dr. Luiz Gonzaga do Prado Filho, pelo apoio e amizade;

- aos meus pais Deise e Odacir e aos meus irmãos Kedilei, Karina e Klauber;

- aos amigos do Laboratório de Genética de Leveduras, Ana Maria Brancalion Giacomelli, Juan Lucas Argueso e Jefferson Willians de Gaspari;

- aos amigos do Laboratório de Biologia Celular (UNIFESP), Adriana Pardini Vicentin, Meire loshie Hiyane, Maria Luiza Bravo da Silva, Regina Maria Catarino, Angela Rico de Souza, Denise C. André e Creuza R. de Oliveira;

- à Gisele, Luiz Fernando e Maria Helena, pelo imenso carinho com que me receberam durante este tempo;

- aos amigos Marcelo Dornelas e Thaís Priscila S. e Silva;

- à CAPES, pela bolsa de Mestrado. 


\section{SUMÁRIO}

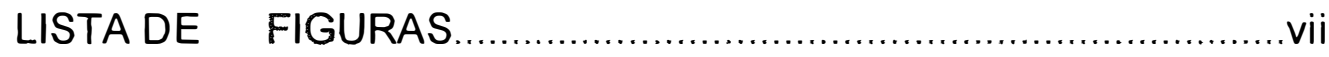

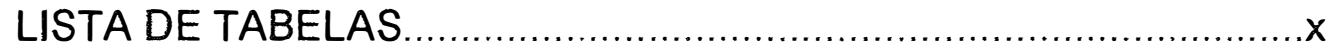

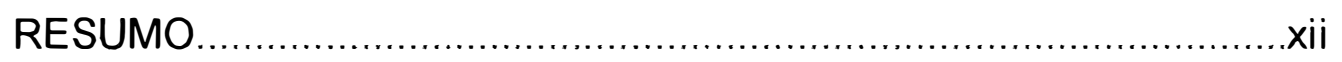

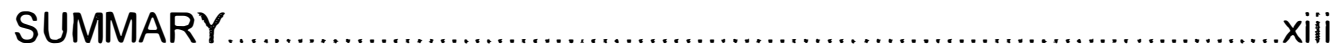

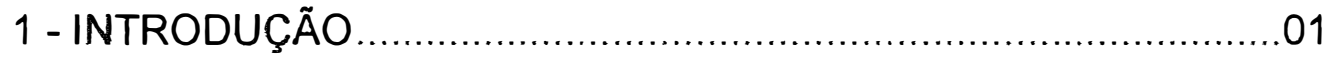

2 - REVISÃO DE LITERATURA ............................................ 03

2.1 - Metodologias utilizadas para a diagnose e con-

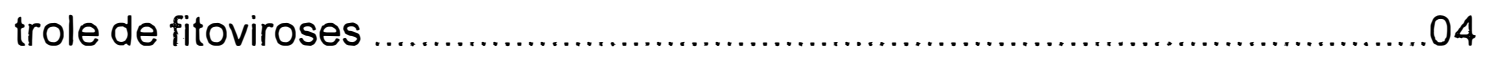

2.2 - Produção de Anticorpos Monoclonais .........................07

2.3 - Diagnóstico de doenças de plantas com anticorpos

monoclonais

2.4 - Diagnóstico e controle do ToMV

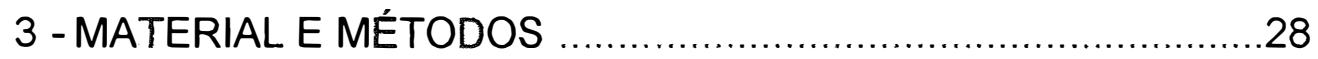

3.1 - Antígeno .................................................28

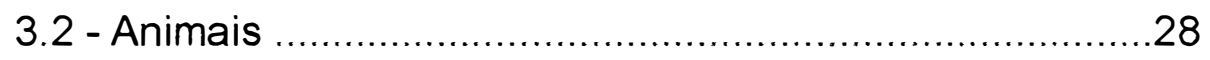


3.3 - Preparo do anticorpo

3.3.1 - Imunização de Camundongos .................................29

3.3.2 - Imunização de Coelhos ………................................30

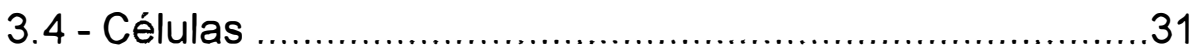

3.5 - Obtenção de "Feeder Layer" de Macrófagos ................32

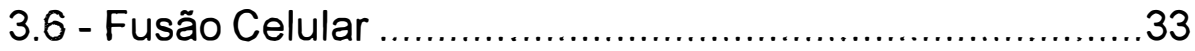

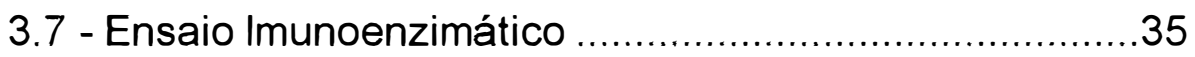

3.8 - Congelamento e Descongelamento de Células ...........37

3.9 - Clonagem dos melhores Híbridos ...............................38

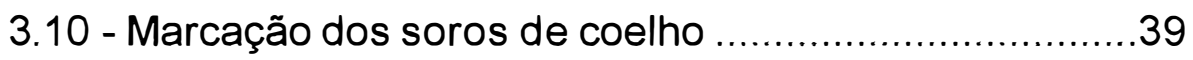

3.10.1 - Purificação de soro de coelho anti -ToMV em

Proteina-A 39

3.10.2 - Acoplamento dos anticorpos com Biotina 40

3.10.3 - Acoplamento dos anticorpos com Peroxidase ......41

3.11 - Ensaio Imunoenzimático Quantitativo .......................42

3.12 - Isotipagem dos anticorpos monoclonais ...................43

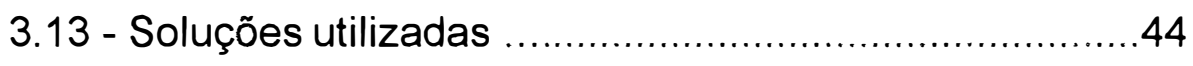

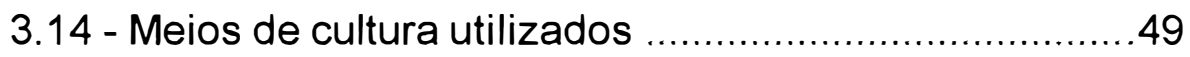

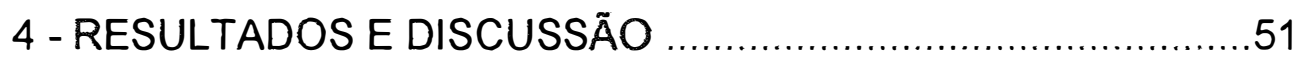

4.1 - Intervalo entre as imunizações ..................................51

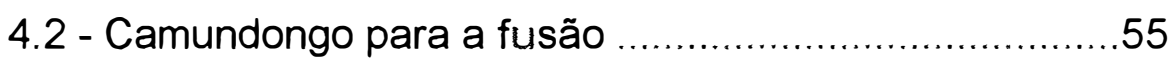


4.3 - Resultado do antissoro policlonal de camundongo contra o ToMV .59

4.4 - Antissoros de coelho contra o ToMV 62

4.5 - Ensaio dos anticorpos de coelho anti -ToMV acoplados com Biotina e Peroxidase 64

4.6 - Titulação dos anticorpos monoclonais 67

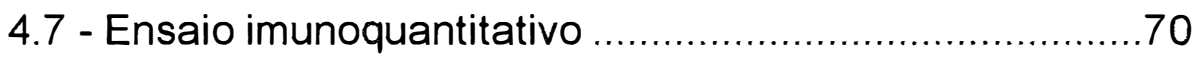

4.8 - Isotipagem dos anticorpos monoclonais 72

5 - CONCLUSÕES 78 


\section{LISTA DE FIGURAS}

FIGURA

PÁGINA

1 Diferenças de D.O. observadas entre antissoros obtidos de camundongos (CA) de lotes diferentes que foram imunizados com ToMV, a intervalos de 15 e 30 dias (números 1 e 2 , respectivamente), em placas sensibilizadas com TMV (letras "a" e "b") e em placas sensibilizadas com ToMV ( letras "c" e "d")

2 Curvas representando os resultados em D.O. a $492 \mathrm{~nm}$, dos antissoros dos camundongos 1, 2, 3 e 4, referentes a última imunização, onde CA NORMAL refere-se ao camundongo controle, que não foi imunizado; CA 1, camundongo 1 ; CA 2, camundongo 2 ; CA 3, camundongo 3 e CA 4, camundongo 4. As diluições 1, 2, 3 e 4 representam respectivamente 1:400, 1:800, 1:1600 e 1:3200

3 Titulação dos antissoros do camundongo 3, imunizado com ToMV em teste de ELISA com TMV, onde C3 SORO1, corresponde ao antissoro do camundongo 3 após a primeira imunização, da mesma forma até che- 
gar a C3 SORO4, correspondente ao camundongo 3 após a quarta imunização 60

4 Titulação dos antissoros do camundongo 3, imunizado com ToMV em teste de ELISA com ToMV, onde C3 SORO1, corresponde ao antissoro do camundongo 3 após a primeira imunização, da mesma forma até chegar a C3 SORO4, correspondente ao camundongo 3 após a quarta imunização

5 Resultados obtidos em D.O. a $492 \mathrm{~nm}$, do antissoro policlonal de coelho obtido após a última imunização, testado em placas de ELISA sensibilizadas com TMV e TOMV

6 Gráfico de D.O. a $492 \mathrm{~nm}$, dos anticorpos monoclonais selecionados, em ELISA sensibilizado com ToMV e com TMV

$7 \quad$ Gráfico dos resultados obtidos em D.O. a $492 \mathrm{~nm}$, no ensaio de quantificação (Sanduiche duplo de ELISA), 
utilizando soro policlonal de coelho anti-ToMV - ToMV anticorpo monoclonal - conjugado marcado com peroxidase

8 Resultados da isotipagem dos anticorpos 8G7G2 (A) e 8C2F12 (B) comparados com os controles positivo e negativo do "kit" utilizado .76

9 Resultados da isotipagem dos anticorpos $8 \mathrm{C} 12 \mathrm{H} 12$ (C) e 10H9F9 (D) comparados com os controles positivo e negativo do "kit" utilizado 


\section{LISTA DE TABELAS}

TABELA

PÁGINA

1 ELISA realizado com aantissoro das duas melhores fêmeas de camundongos imunizados com ToMV. Dados expressos em Densidade Ótica (D.O.) a 492 nm, após a última imunização. Na tabela, os números 1 e 2 representam, respectivamente, intervalo de 15 e 30 dias. As letras "a"e "b" - camundongo imunizado com ToMV em ELISA sesibilizado com TMV; "c" e "d" - camundongo imunizado com ToMV em ELISA sensibilizado com TMV 52

2 Resultados de D.O. a $492 \mathrm{~nm}$, dos camundongos 1, 2, 3 e 4, de cada imunização, onde IMU 1 - primeira imunização; IMU 2 - segunda imunização e IMU 3 - terceira imunização. DIL. refere-se a diluição dos antissoros e $\mathrm{CAN}$, ao camundongo controle 
3 Resultado de D.O. a $492 \mathrm{~nm}$ dos antissoros do camundongo escolhido para a fusão (CA 3) testado em ELISA sensibilizado com ToMV (A) e TMV (B), respectivamente .58

$4 \quad$ Resultados de D.O. a $492 \mathrm{~nm}$, dos soros policlonais de coelho marcados com biotina e com peroxidase, testados emELISA sensibilizado com TMV e com ToMV, utilizando diferentes diluições dos antissoros de coelho não marcados, onde PERO refere-se aos antissoros marcados com peroxidase e BIOT, aos antissoros marcados com biotina. NORMAL refere-se ao soro de coelho não imunizados

5 Resultados de D.O. a $405 \mathrm{~nm}$, do teste de isotipagem, com os quatro anticorpos monoclonais, utilizando o "Kit Immuno Select" 


\title{
PRODUÇÃO DE ANTICORPOS MONOCLONAIS CONTRA O VÍRUS DO MOSAICO DO TOMATEIRO (TOMV)
}

\author{
Autora: Keila Maria Roncato Duarte \\ Orientador: Prof. Dr. Flavio Cesar Almeida Tavares
}

\section{RESUMO}

O vírus do mosaico do tomateiro (ToMV) causa sérios prejuízos na cultura do tomate e sua identificação, uma vez instalado na planta, torna-se difícil devido a grande semelhança com o vírus do mosaico do fumo (TMV). Pelo fato do ToMV ser resultado de uma mutação do TMV, técnicas utilizadas, aqui no Brasil, além de não permitirem uma perfeita identificação destes dois vírus.

Partindo disso, foram produzidos quatro anticorpos capazes de reconhecerem o ToMV e não apresentarem reação cruzada com o TMV, pelo fato de serem específicos para epitopos do ToMV, sendo o anticorpo 8G7G2 um monoclonal e os outros três anticorpos ainda policlonais, mostrando que técnicas empregadas na imunologia, especialmente a produção de anticorpos monoclonais, podem ser aplicadas na agricultura a fim de solucionar problemas de diagnóstico de patógenos muito próximos estruturalmente. 


\title{
PRODUCTION OF MONOCLONAL ANTIBODIES AGAINST THE TOMATO MOSAIC VIRUS (TOMV)
}

\author{
Author: Keila Maria Roncato Duarte \\ Adviser: Prof. Dr. Flavio Cesar Almeida Tavares
}

\section{SUMMARY}

The tomato mosaic virus (ToMV) causes great losses on tomato crops yield and its identification becomes difficult, once the disease has been installed on the field, because the ToMV is very similar to tobacco mosaic virus (TMV). Mainly due to the fact that ToMV is a TMV muted virus, techniques used in Brazil do not allow a perfect identification between those viruses.

Keeping that on mind, four monoclonal antibodies capable of recognize ToMV and didn't show cross-reactions with TMV, were produced, based on the specificity of ToMV epitopes. One of them, $8 G 7 G 2$ is a monoclonal antibody and the other three antibodies, are policlonal. These results show that the use of immunological techiniques, especially monoclonal antibodies, can be applied to agriculture in the way to solve problems of identification of very close related pathogens. 


\section{1 - INTRODUÇÃO}

O vírus do mosaico do tomateiro (ToMV) infecta tomateiros comprometendo a produção. Este vírus foi identificado recentemente no Brasil, havendo assim, da mesma forma que em outros países, uma preocupação quanto à diagnose correta e ao controle desta virose.

Dois aspectos justificam o trabalho com este vírus em particular. Primeiramente, de modo geral, os vírus não têm controle químico adequado, são parasitas obrigatórios e de difícil diagnóstico por sintomas. Por outro lado, o fato de o ToMV causar danos para o tomateiro, reforça a importância deste trabalho, pois o tomate é a olerícola mais consumida no mundo e é hospedeira de mais de 200 patógenos diferentes, dentre os quais, 20 \% são patógenos virais (JONES et al., 1991).

Aliado a este fato, não é possivel se fazer uma distinção entre o ToMV e o vírus do mosaico do fumo (TMV), devido a grande similaridade que ambos apresentam, não sendo possível diferenciá-los utilizando sorologia baseada em antisoros policlonais. Desta forma, o ToMV foi escolhido por se tratar de um variante do TMV, que até 1959, MARKHAM relatava como sendo uma linhagem do TMV mas a partir de 1982, VAN 
REGENMORTEL, passa a classificar o TOMV como um outro vírus distinto do TMV, apesar de serem taxonomicamente muito semelhantes.

O uso de anticorpos monoclonais para a identificação do ToMV, tendo em vista que no Brasil testes de diagnóstico de doenças agronomicamente importantes utilizando esta tecnologia só são possíveis com "kits" importados (o que encarece bastante o teste e torna sua utilização pouco disponivel e praticamente inacessível aos produtores rurais), seria de grande importância, primeiro por resolver o problema da diferenciação dos dois vírus e também por introduzir a utilização de anticorpos monoclonais no diagnóstico de doenças de planta, tecnologia até então utilizada somente na área médica e veterinária.

Este trabalho tem por objetivos, portanto, produzir e utilizar anticorpos monoclonais a fim de diferenciar o ToMV do TMV, comparando com o uso de antisoros policlonais. 


\section{2 - REVISÃO DE LITERATURA}

Diversos recursos têm sido empregados para a diagnose precisa de doenças, principalmente aquelas causadas por vírus. No estudo de viroses, são problemas 0 isolamento do agente causal e sua diferenciação em relação a outros vírus geneticamente próximos. Desde que a metodologia de isolamento já é bastante conhecida, faz-se necessário desenvolver um teste sensivel para detectar quantidades mínimas do vírus e distinguí-los de outros vírus semelhantes.

Considerando estes aspectos, nesta revisão apresentam-se as metodologias geralmente empregedas para o diagnóstico e controle de fitoviroses e o uso de anticorpos para este fim.

\section{1 - Metodologias utilizadas para o diagnóstico e controle de}

\section{fitoviroses}

As viroses causam perdas significativas na agricultura e todo esforço é empregado para o seu controle. Este trabalho inicia-se pela identificação correta do agente causal com precisão, para que sejam 
estabelecidas as estratégias de controle adequadas, sejam variedades resistentes, sementes ou mudas certificadas, eliminação do vetor, zoneamento da produção, erradicação de fontes de inóculo, entre outras (BERGAMIN FILHO, 1978).

Tradicionalmente, as viroses são diagnosticadas baseadas em sintomas na planta atacada ou em plantas indicadoras (CANER et al., 1990); no modo de transmissão e tipo de vetor e em testes sorológicos convencionais (SEQUEIRA, 1992); observação de inclusões ao microscópio ótico; detecção de partículas em extratos ou efeitos citopáticos ao microscópio eletrônico, (KITAJIMA, 1991) ou ainda, segundo ANDERSON (1983) através de eletroforese bidimensional.

Além destas metodologias de diagnóstico, atualmente procura-se utilizar testes mais sensíveis e, principalmente mais rápidos, como testes sorológicos de maior sensibilidade, detecção de RNA de fita dupla, sondas moleculares e microscopia eletrônica.

A detecção de RNA de fita dupla consiste em detectar o RNA viral na forma de fita dupla, pareada com sua fita complementar, em extratos de plantas infectadas, submetidas à eletroforese. Com isto, é possivel deduzir a existência do vírus mas não identificá-lo.

As sondas moleculares têm sido muito utilizadas para sequenciar cadeias de nucleotídeos de ácido nucleido viral como também 
amplia a possibilidade de se usarem fragmentos complementares de DNA (cDNAs) como sondas para fins de diagnose.

A microscopia eletrônica, especialmente as técnicas sorologicamente específicas (MEIAD), tem sido de grande ajuda no estudo das doenças causadas por vírus, como películas tratadas com anti-soro específico (KITAJIMA, 1991).

O uso de anticorpos conjugados a marcadores em imunoensaios de ligação enzimática - ELISA ("Enzyme-Linked Immunosorbent Assay") melhoraram consideravelmente a sensibilidade dos testes sorológicos convencionais (CLARK \& ADAMS, 1977; AL MOUDALALL et al., 1984; KITAJIMA, 1991), podendo ser identificados deste modo, quantidades bastante pequenas de partículas virais, consumindo quantidades mínimas de reagentes e anti-soros, sendo de grande utilização especialmente para os vírus que ocorrem em baixas concentrações e que consequentemente causam poucos ou nenhum sintoma, a não ser queda na produção (VOLLER et al., 1976).

VAN REGENMORTEL \& BURCKARD (1980) conseguiram detectar estirpes do TMV através de ELISA indireto, utilizando a capa viral como antígeno na imunização de coelhos, galinhas e cabras, sendo possivel diferenciar com alta precisão as estirpes TMV, Y -TAMV, U2 e HR deste vírus. 
Outra metodologia utilizada é a extração de proteínas de plantas infectadas, fazendo-se sua separação por eletroforese e, detectando antígenos virais com anticorpos marcados (técnica de "Immunoblot"), após sua transferência para uma membrana de nitrocelulose (KITAJIMA, 1991).

Apesar desta grande quantidade de metodologias disponíveis para o diagnóstico de vírus, o uso de anticorpos monoclonais para identificação de doenças de plantas, onde a formação de imunoglobulinas específicas para um dado epitopo do antígeno é induzida em animais-teste, ou seja, isolamento de linhagens de hibridomas produtoras de anticorpos com uma única especificidade, permitem discriminar sutis diferenças entre estirpes de vírus muito próximas ou separar complexos virais.

\section{2 - Produção de anticorpos monoclonais}

Para se obter um "kit" de diagnóstico, dentre as técnicas disponíveis, a que oferece maior confiabilidade e maior sensibilidade é o uso de anticorpos monoclonais. Dentro dessa metodologia, desenvolvida por KOHLER \& MILSTEIN (1975), cada anticorpo produzido é diferente de outro pelo fato que cada clone de linfócito produz um anticorpo que não é idêntico 
ao produzido por outros clones, mas que no conjunto, todos esses anticorpos irão agir contra o antígeno que induziu a sua formação.

Estruturalmente, os anticorpos (ou imunoglobulinas) são formados por quatro cadeias, sendo divididas de modo a formarem duas cadeias leves (de peso molecular ao redor de $25 \mathrm{Kd}$ ) e duas cadeias pesadas ( de peso molecular entre 50 a $77 \mathrm{Kd}$ ), formando uma estrutura semelhante a um "Y", em cujas extremidades superiores encontram-se as regiões variáveis da imunoglobulina responsáveis pela ligação com o antígeno e consequentemente, pela variabilidade e especificidade de cada anticorpo .

A cadeia leve, para a maioria dos vertebrados, pode ser do tipo kappa ou lambda enquanto que a cadeia pesada determina a classe e subclasse das imunoglobulinas.

Cinco classes diferentes de imunoglobulinas podem ser encontradas ( $\lg G, \lg A, \lg M, \lg D$ e $\lg E)$, diferenciando entre si por tamanho, carga, composição de aminoácidos e conteúdo de carboidratos. Dentro de cada classe há pequenas diferenças que permitem uma divisão em subclasses, principalmente nas IgG.

As imunoglobulinas mais frequentes são a $\lg G, \lg A$ e $\lg M$ e tem por principais características, individualmente, o seguinte: as IgG perfazem cerca de $70-75 \%$ do total de imunoglobulinas e são anticorpos responsáveis pela resposta secundária; IgA, representando 15 a $20 \%$ das 
imunoglobulinas, sendo predominante nas secreções como saliva, leite, colostro, etc e, finalizando as IgM, que representam $10 \%$ das imunoglobulinas e são encontradas nos espaços intra-vasculares, também conhecidas como anticorpos precoces (ROITT et al., 1992).

Essa diferenciação ocorre devido aos sítios indutores conhecidos como epitopos no antígeno, que devem ser sempre de origem proteica para que haja a formação de anticorpos, assim, haverão anticorpos que se ligarão a todos os epitopos do antígeno, combatendo-o. Partindo disso, o organismo atacado necessita desenvolver o máximo de diversidade de anticorpos para assegurar a eliminação do antígeno.

As células produtoras de anticorpos têm a capacidade de produzir uma enorme diversidade de imunoglobulinas, sendo que cada célula produz um anticorpo capaz de reconhecer um único epitopo que o antígeno possua. Desta forma, ao se clonarem células produtoras de anticorpos, seleciona-se clones com maior especificidade de reconhecimento deste determinado antígeno, eliminando a possibilidade de reação cruzada com outro antígeno muito próximo estruturalmente. Outra característica das células produtoras de anticorpos está no fato de que elas não crescem em meio de cultura e apresentam uma vida muito curta.

A tecnologia de produção de anticorpos monoclonais pode ser resumida na fusão de células tumorais (mieloma) de camundongos com células provenientes do baço de outro camundongo previamente imunizado 
com o antígeno, obtendo assim hibridomas que reunem a característica de produção de anticorpos à imortalidade das células tumorais (SHULMAN et al., 1985).

Esses hibridomas uma vez clonados, podem oferecer anticorpos monoclonais altamente específicos, capazes de caracterizar e diferenciar microrganismos, viroses vegetais e animais, poluentes, contaminantes de alimentos, podendo também serem usados na terapia genética de doenças humanas, entre outras aplicações (KEARNEY et al., 1979).

$\mathrm{Na}$ agricultura, o uso de anticorpos monoclonais, embora ainda de maneira bastante exploratória, vem solucionando vários problemas que as metodologias utilizadas já não conseguem fazer de maneira eficiente, como a identificação de microrganismos muito semelhantes, diagnose de doenças assintomáticas, identificação de proteínas de interesse, detecção de poluentes e agentes tóxicos em alimentos e rações, enfim, uma variedade de opções onde os anticorpos monoclonais são altamente eficientes e economicamente viáveis.

As vantagens do uso de anticorpos monoclonais substituindo os soros policlonais pode ser exemplificada, segundo CAMPBELL (1984) com base nas seguintes características: 
soro policlonal anticorpos monoclonais

\begin{tabular}{|c|c|c|}
\hline \multicolumn{3}{|c|}{ especificidade } \\
\hline afinidade & $\begin{array}{l}\text { variável de acordo } \\
\text { com o sangue }\end{array}$ & $\begin{array}{c}\text { selecionada durante } \\
\text { clonagem }\end{array}$ \\
\hline $\begin{array}{l}\text { produção de } \\
\text { anticorpo } \\
\text { necessária }\end{array}$ & $1 \mathrm{mg} / \mathrm{ml}$ & $\begin{array}{l}100 \mathrm{mg} / \mathrm{ml} \mathrm{em} \text { cultura } \\
20 \mathrm{mg} / \mathrm{ml} \text { em ascite }\end{array}$ \\
\hline $\begin{array}{l}\text { contaminação } \\
\text { por outras } \\
\text { Imunoglobulinas }\end{array}$ & quase $100 \%$ & $\begin{array}{l}\text { zero em cultura } \\
10 \% \text { em ascite }\end{array}$ \\
\hline
\end{tabular}

Segundo YEWDELL \& GERHARD (1981), as vantagens podem ser resumidas em especificidade única e produção ilimitada, após que a cultura de hibridomas estar estabelecida.

Apesar do uso de anticorpos monoclonais apresentar todas estas vantagens em relação aos soros policlonais, a principal desvantagem desta tecnologia é o custo, sendo portanto necessário que realmente haja um problema que a técnica de sorologia convencional ( com soros policlonais) não seja capaz de resolver de forma adequada.

Os camundongos utilizados para imunização, de um modo geral, pertencem à linhagem BALB/c, que possue como principal característica a alta produção de anticorpos. Já as células de mieloma (linfoma produzido a partir de células B) têm a capacidade de crescerem indefinidamente em meio de cultura sintético mas possuem algumas marcas 
genéticas que possibilitam a seleção das células fundidas, já que as células de mieloma são deficientes para a enzima hipoxantina guanina fosforibosil transferase (HPGRT'), o que significa que elas não possuem a enzima responsável pela via principal de síntese de DNA, utilizando uma via de salvação de síntese de DNA. Logo após a fusão, os hibridomas são colocados em meio seletivo contendo hipoxantina, aminopterina e timidina (meio HAT), que inibe a via de salvação de síntese de DNA, sendo assim, somente aquelas células que realmente se fundiram irão crescer, pois a síntese de DNA é provida pela célula produtora de anticorpos (que é $\mathrm{HPGRT}^{+}$) e a imortalidade das células bem como a capacidade de crescimento sem diferenciação em meio sintético, vem das células de mieloma (GODING, 1986).

Os primeiros anticorpos monoclonais produzidos contra vírus foram feitos por KOPROWSKI et al. (1977), GERHARD et al. (1978) e WIKTOR \& KOPROWSKI (1978) e desde então, a aplicação dos anticorpos monoclonais contra os vírus em geral, tem sido cada vez mais estudadas.

As principais características a serem avaliadas na produção de anticorpos monoclonais contra viroses são, segundo Mc CULLOUGH (1986): a neutralização viral, com respeito aos mecanismos virais como inibição, adsorção, penetração e pós-penetração, que podem ser neutralizados com o uso de anticorpos monoclonais, relacionados com a patogenicidade do vírus; a afinidade e especificidade dos anticorpos 
monoclonais dependente do genótipo e fenótipo dos linfócitos $B$ dos quais o hibridoma se originou e, finalizando, a identificação dos epitopos, que são determinantes antigênicos responsáveis pelo reconhecimento do antígeno.

\section{3 - Diagnóstico de doenças de plantas com} anticorpos monoclonais

A deteç̧ão de fitoviroses com 0 uso de anticorpos monoclonais tem sido bastante utilizada por se tratar de um grupo de patógenos que não apresenta controle químico eficiente e, portanto, faz-se necessário um diagnóstico precoce e confiável, como descrito anteriormente.

Diversos anticorpos têm sido produzidos para a diagnose de fitoviroses. BASTIN et al. (1982) realizaram um trabalho testando sete modificações do teste de ELISA para a titulação de anticorpos monoclonais produzidos contra o TMV, um patógeno considerado por eles como modelo para tais testes. Cinco das sete modificações mostraram-se bastantes eficientes, embora duas delas mostraram maior sensibilidade na detecção do antígeno.

Num trabalho realizado por HALK et al. (1984), 14 linhagens estáveis de hibridoma secretando anticorpos monoclonais contra a mancha anelar necrótica do pêssego - NRSV ("prunus necrotic ringspot") , o mosaico da maça - ApMV ("apple mosaic virus"), vírus da estria do tabaco - 
TSV ("tobacco streak") e do mosaico da alfafa - AMV ("alfafa mosaic virus") foram selecionadas, sendo utilizado como antígeno uma mistura dos quatro vírus. Apenas cinco dos 14 clones foram realmente utilizados por apresentarem resultados em ensaios de dupla imunodifusão em ágar, embora todos apresentassem títulos altos no teste de ELISA, o que foi importante para o propósito do trabalho que no caso se limitava à classificação de isolados desses vírus.

Em 1985, HALK \& DE BOER descreveram 31 vírus contra os quais já se produziam anticorpos monoclonais. Entre os hospedeiros destes vírus, encontravam-se diversas espécies de interesse agronômico como batata, milho, soja, laranja, feijão, tomate e arroz.

SHERWOOD et al. (1987) produziram anticorpos monoclonais contra o PMV ( "peanut mottle virus" ) que ataca o amendoim. O isolado do vírus foi multiplicado e purificado de plantas de ervilha ( Pisum sativum L.). Os hibridomas foram produzidos e 54 clones estáveis produtores de anticorpos anti-PMV foram selecionados através de teste de ELISA indireto e todos foram isotipados como lgG1.

Estes clones foram testados a fim de se determinar a presença de reação cruzada com diversos outros vírus relacionados ( "wheat streak mosaic virus", "peanut stripe virus", "watermelon mosaic virus-1", "potato virus Y", "brome mosaic virus", "wheat soilborne mosaic virus", "turnip mosaic virus" e "tomato spotted wilt virus"). Dos 54 clones, três foram 
escolhidos e não reagiram com nenhum destes vírus, servindo portanto como um "kit" de diagnóstico específico para o PMV.

BAHRANI et al. (1988) obtiveram anticorpos monoclonais, obtidos de BALB/c, contra o vírus do mosaico do trigo - WSBMV ("wheat soil-borne mosaic virus"). Esse vírus causa mosaico, enfezamento e perfilhamento excessivo em plantações de trigo de inverno, representando uma perda de $50 \%$ da produção de grãos. O vírus purificado foi obtido de plantas de Triticum aestivum cv. Vona, infectadas com o patógeno. Quinze dos 120 clones produzidos foram caracterizados e mantidos em cultura. Os clones foram posteriormente isotipados, sendo todos pertencentes à classe IgG e testes demonstraram que todos os anticorpos monoclonais reagiram contra 4 isolados do WSBMV. Testes de ELISA do tipo sanduíche com proteína A e "dot-immunobinding" detectaram, respectivamente, 1 a $2 \mathrm{ng} / \mathrm{ml}$ e 100 a $500 \mathrm{ng} / \mathrm{ml}$ do vírus em amostras de folhas de trigo.

CULVER \& SHERWOOD (1988) desenvolveram através de anticorpos monoclonais, "kits" para a detecção do vírus da estria da semente de amendoim - PStV ("peanut stripe virus"), que infecta sementes de amendoim (Arachis hypogaea L.). O teste de ELISA Indireto foi utilizado para a titulação de anticorpos policlonais e monoclonais, como para a combinação deles. Os anticorpos monoclonais mostraram-se mais sensíveis, detectando 2,5 $\mathrm{ng} / \mathrm{ml}$ do vírus e detectando o PStV em sementes maceradas e diluídas 
32 vezes, ou seja, uma semente infectada para 32 sementes sadias maceradas juntamente.

Para os testes, foram utilizados os seguintes cultivares: Spanco, Pronto, Tamnut 74, Argentine e Florunner. A obtenção de sementes infectadas foi conseguida fazendo-se o maceramento de folhas de Lupinus albus L., planta teste indicada para reprodução deste patógeno, infectada previamente com o PStV. O maceramento das folhas foi realizado em tampão fosfato $0,01 \mathrm{M}, \mathrm{pH} 8,0$ e, esse macerado foi estriado nas folhas dos cultivares ainda no estágio de plântulas. Uma pequena porção do cotilédone de cada semente foi removido e testado para detectar a presença ou ausência do vírus. As sementes foram então plantadas e um novo teste de ELISA foi feito para as plântulas, juntamente com uma planta testadora (Chenopodium amaranticolor). As sementes plantadas mostraram-se livres de vírus, e o teste de ELISA identificou a presença do patógeno em tecido cotiledonar. Todos os 5 cultivares de amendoim transmitem esta virose em taxas que variam de 0,4 a $5,0 \%$ do total das sementes comercializadas.

GEORGE \& CONVERSE (1988) desenvolveram métodos para enriquecimento de populações de células $B$, necessárias antes da formação de hibridomas contra o vírus do mosaico da couve-flor - CaMV ("cauliflower mosaic virus"), que ataca couve-flor e couve chinesa. O CaMV foi escolhido como modelo para esse estudo pelo fato que a metodologia de purificação e sorologia são bastante compreendidas. 
Os anticorpos monoclonais vieram da imunização de camundongos BALB/c com CaMV isolado de couve chinesa (Brassica pekinensis (Laur.) Rupr.). O enriquecimento das células B pelo processo de imunoadsorção descrito no trabalho, elimina problemas quando se tem mistura de antígenos no desenvolvimento dos hibridomas e conseqüentemente na eficiência dos anticorpos monoclonais produzidos.

Anticorpos monoclonais específicos para o vírus $M$ da batata - PMV ("potato M-virus"), foram preparados por JÄRVEKÜLG et al. (1989). Embora soros policlonais reconhecessem até $40 \mathrm{ng} / \mathrm{ml}$ de PMV em tubérculos de batata, não se conseguiam, com esses soros, diferenciar estirpes do PMV.

O vírus foi purificado de folhas de tomateiro e estirpes fracas, moderadas e severas foram isoladas e caracterizadas. Os controles negativos foram feitos utilizando os vírus PVX, PVY, PVS e PLRV. Após a obtenção dos hibridomas, três clones foram selecionados e detalhadamente caracterizados. Os testes foram feitos utilizando suco de tubérculos infectados dos cultivares Ando, Adretta, Sulev Jógeva Kollane, Alõi, Mavka ou Komsomolets em testes de ELISA indireto.

Os anticorpos reconheceram quantidades inferiores a 10 ng de PVM por $\mathrm{ml}$, chegando a $1 \mathrm{ng} / \mathrm{ml}$. O "kit" produzido detecta tanto o PVX quanto o PVM em suco de tubérculos de batata (Solanum tuberosum) . 
TORRANCE et al. (1988) produziram uma série de anticorpos monoclonais contra o vírus do amarelo necrótico da beterraba BNYW ("beet necrotic yellow vein virus"). Este vírus causa na beterraba açucareira, uma doença conhecida como rizomania e é transmitida pelo fungo Polymyxa betae. Vinte e cinco isolados deste vírus, provenientes de oito países diferentes foram utilizados para a produção dos anticorpos monoclonais. Tais anticorpos, uma vez caracterizados, foram utilizados numa mistura para um "kit" de diagnóstico para folhas de beterraba açucareira e para solos infectados de cada um destes países produtores de açúcar extraída da beterraba.

JONES et al. (1989) fizeram, através de anticorpos monoclonais e soros policlonais a diferenciação dos seguintes vírus que atacam cultivares de framboesa: nepovírus do mosaico arabico - AMV ("arabis mosaic nepovirus") e vírus do mosaico em anel -RRV ("raspberry ringspot neporivus"). O problema original consistia em diferenciar cepas dos vírus em cultivares de framboesa cultivadas na Inglaterra e Escócia, através de infecção natural, inoculação em plantas sadias e inoculação em planta-teste de Rubus.

Através de testes sorológicos com soros policlonais e monoclonais, puderam ser feitas diferenciações entre isolados desses vírus em diferentes locais onde se cultivam diversas variedades de framboesa. 
SHERWOOD et al. (1989) produziram anticorpos monoclonais contra o TSWV ( "tomato spotted wilt virus"), purificado a partir de plantas de Datura stramonium L. infectadas com o vírus. Vários isolados deste vírus foram utilizados para a produção dos anticorpos monoclonais.

A fim de se determinar a atividade sorológica dos anticorpos a diferentes vírus que possuem envelope e parasitam plantas agronomicamente importantes, diversos testes foram conduzidos como PAS-ELISA ( ELISA do tipo sanduíche com proteína A), ELISA indireto e "Dot-Immunobinding Assay". Este foi o primeiro trabalho de produção e utilização de anticorpos monoclonais detectando vírus contendo envelope e que atacam plantas.

KAWAl et al. (1991) produziram anticorpos monoclonais contra o CTLV ("citrus tatter leaf virus"), causador do enrolamento das folhas de citros. Os hibridomas foram testados juntamente com soros policlonais obtidos e purificados de Chenopodium quinoa infectados com CTLV em teste de ELISA indireto. Três clones foram escolhidos e todos foram isotipados como sendo $\lg \mathrm{G} 1$, e todos os três reagiram positivamente com 20 isolados do vírus CTLV e com dois isolados do vírus do enrolamento do caule da macieira - SGCV ("stem grooving capillo virus"). Os três anticorpos monoclonais detectaram vírus, através de ELISA direto em seiva de Chenopodium quinoa diluída 1: 516 vezes e em seiva de plantas de citros diluída 1: 64 vezes. 
Anticorpos monoclonais específicos para detecção de vírus do mosaico da macieira - ApMV ("apple mosaic ilarvirus") foram obtidos através de fusão de mieloma com células secretoras de anticorpos produzidas por camundongo BALB/c imunizado com 0 isolado P86 deste vírus. Nove clones foram isotipados e caracterizados em teste de ELISA. Todos os clones detectaram o ApMV em diferentes habitats naturais infectados. Não houve reações quando os clones foram testados com plantas sadias ou com amostras de outras rosáceas (pêssego, nectarina, maçã, etc) infectadas com o PNRV ( "prunus necrotic ringspot ilarvirus") (PASQUINI \& BARBA, 1991).

HATAYA et al. (1994) utilizaram anticorpos monoclonais específicos contra o PVY, que infecta a batata, utilizando duas estirpes PVY - O e PVY - T, a fim de testarem amostras supostas destes vírus. Das amostras, $22 \%$ apresentaram reação positiva com o anticorpo monoclonal contra PVY - 0; 55\% das amostras apresentaram reação positiva com o anticorpo monoclonal PVY - T; $17 \%$ das amostras apresentaram reação positiva com ambos os anticorpos monoclonais e apenas $65 \%$ das amostras não apresentaram reação com nenhum dos dois clones.

As amostras que não reagiram positivamente com os dois clones, foram submetidas a testes como sequenciamento de amino ácido da capa proteica e análise mais detalhada dos epitopos existentes. $\mathrm{O}$ isolado destas amostras restantes foi determinado como PVY- 36. Com o teste de 
sequenciamento de amino ácidos, o PVY-36 apresentou $94 \%$ de semelhança com o isolado PVY - T e $97 \%$ de semelhança com o isolado PVY -O. De acordo com estes resultados, foi possível determinar que o PVY-36 pertencia ao isolado PVY G016, proveniente da Alemanha.

Outros patógenos também já são identificados utilizando a técnica de produção de anticorpos monoclonais, como a diagnose de doenças bacterianas (DE BOER et al., 1988; Mc LAUGHLIN et al., 1989; PERMAR \& GOTTWALD ,1989; BHUNIA \& JOHNSON ,1992; WARD et al.,1993 e OLSEN et al. ,1994), para a detecção de substâncias tóxicas de origem fúngica, em alimentos prontos para consumo e em grãos colhidos e armazenados (HASTINGS et al., 1988; BARNA-VETRÓ et al., 1994 e BREUIL et al.,1992).

Além destes patógenos, um grupo de doenças bastante difícil de diagnosticar é aquele causado por Espiroplasmas e Fitoplasmas (microrganismos do tipo micoplasmas), contra os quais já existem também anticorpos monoclonais produzidos (JORDAN et al., 1989; CHEN \& JIANG, 1988; CLARK et al.,1989).

$\mathrm{Na}$ produção de anticorpos monoclonais ou policlonais para diagnose de doenças de plantas, algumas modificações, às vezes, tornam-se necessárias, como a determinação do intervalo entre imunizações mais adequado ao patógeno que se deseja trabalhar. 
Devido à grande quantidade de protocolos existentes, de modo a otimizar e, eventualmente, aumentar a probabilidade de obtenção de anticorpos monoclonais que sejam relevantes, específicos e com grande afinidade para o antígeno, no caso, o ToMV.

Existem alguns protocolos básicos como o citado por BASTIN et al. (1982) que recomendavam, para antígenos solúveis, como é o caso de vírus, uma primeira imunização no dia "1", uma segunda no dia "28" e as subsequentes a intervalos de 90 dias.

CAMPBELL (1984) determina um intervalo entre as imunizações de 2 e 3 semanas para proteína purificada de antígenos do tipo vírus e bactérias. Este intervalo de tempo é recomendado por vários autores.

DIETZGEN \& SANDER (1982) utilizaram o intervalo de 42 dias entre as imunizações com o vírus TMV, realizando também o teste de ELISA indireto para a determinação dos títulos obtidos.

CLARK et al. (1989) a partir de fitoplasmas (do tipo MLO) que atacam prímulas, obtiveram soros policlonais e produziram anticorpos monoclonais, utilizarando intervalos que variaram entre 2 e 3 semanas. TORRANCE et al. (1988) preferiram o intervalo de 20 dias entre as imunizações com o vírus da necrose amarela de beterraba (BNWW) ("beet necrotic yellow vein virus") e JÄRVEKÜLG et al. (1989), o intervalo entre as imunizações com 0 vírus $M$ da batata de 3 semanas, para ensaios de imunofluorescência e para a produção de anticorpos monoclonais. 
Um outro grupo de pesquisadores usaram intervalos inferiores a este citado. CHEN \& JIANG (1987) utilizaram um intervalo de 7 dias entre as imunizações, para a produção de soro policlonal e produção de anticorpos monoclonais contra o ficoplasma que causa o nanismo arbustivo do milho (MBSP), o mesmo para o PStV ("peanut stripe virus"), que ataca sementes de amendoim (CULVER \& SHERWOOD, 1987). Ambos os trabalhos relatam ótimos resultados na titulação dos soros em testes de ELISA.

$$
\text { Um segundo grupo de pesquisadores recomenda }
$$
intervalos bastante longos entre as imunizações como por exemplo HALK et al. (1984) que utilizaram apenas duas imunizações para obtenção de soro contra seis vírus ( AMV - vírus do mosaico da alfafa; PDV - "prune dwarf virus"; TAMV- "tulare apple mosaic virus" e estirpes do NRSV, ApMV e TSVvírus que atacam plantas da família das Rosaceae), com um intervalo de 120 dias entre as imunizações. PERMAN \& GOTTWALD (1989) usaram um intervalo de 45 dias entre as imunizações para obtenção de soro contra a bactéria Xanthomonas campestris em ensaios com citros.

Em vista desta divergência, fez-se necessário determinar um intervalo ideal entre imunizações para o ToMV. 


\section{4 - Diagnóstico e controle do ToMV}

O ToMV, identificado e caracterizado no município de Conchal, SP (CANER et al., 1990), teve seu primeiro relato em duas regiões produtoras de tomate, localizadas na Zona da Mata e no Triângulo Mineiro, no estado de Minas Gerais, sendo constatada sua ocorrência em $73 \%$ das amostras (FERNANDES et al., 1983).

A identificação do ToMV, ocorrendo em tomateiros no Estado de São Paulo, é da maior importância, pois a disseminação do vírus pode se dar por contato de folhas, operações culturais, e, principalmente, através de sementes, onde o vírus se localiza na mucilagem externa e, algumas vezes, no endosperma ( HOLLIHGS \& HUTTINGA, 1976), sendo assim, necessário um teste capaz de diagnosticá-lo antes do plantio das sementes.

O ToMV constitui-se uma virose que em potencial pode se tornar economicamente importante, pois resulta em grandes perdas na produção de tomates, especificamente na Europa. Os sintomas no tomateiro são mosaicos de áreas verde claro e escuro nas folhas; o enrolamento, a redução e afilamento de folíolos, além de apresentar aspecto bolhoso nas folhas e aspermia de frutos.

Como características gerais do ToMV, este vírus faz parte do grupo dos Tobamovírus; contém RNA de fita simples como material 
genético; possui tamanho de 300 por $18 \mathrm{~nm}$ e representa um dos vírus mais persistentes e infecciosos de que se tem conhecimento.

Sua transmissão pode se dar através de ferramentas e pelo manuseio humano, assim como por sementes, o que o torna mais problemático que o TMV, cuja transmissão não se dá através de sementes. O vírus pode permanecer ativo por anos, sendo bastante sensível à umidade do solo (em solos secos, chega a permanecer latente por dois anos e em solos úmidos, por apenas um mês), tendo-se o cuidado de eliminar os restos culturais de forma a não serem fonte de inóculo para o solo. A ocorrência de insetos vetores na transmissão desses vírus ainda é desconhecida.

Apesar do ToMV causar prejuizos para o tomateiro, existe uma gama bastante grande de hospedeiros intermediários, nos quais ele se aloja, sendo mais comuns as plantas das famílias das Aizoaceae, Amaranthaceae, Chenopodiaceae, Scrophulariaceae e Solanaceae.

No Brasil, o controle dessa virose resume-se no uso de sementes sadias, fuga de áreas contaminadas, rotação de cultura, e, finalmente, um manejo adequado ao plantio de qualquer cultura. BOS (1983) cita o tratamento térmico para sementes secas de tomate, utilizando ar quente a $70-76{ }^{\circ} \mathrm{C}$ por 1 a 3 dias, embora este método não erradique o vírus do embrião da semente e, para fazê-lo, mataria o embrião e inviabilizaria as sementes. Na Europa, faz-se menção do tratamento de 
sementes utilizando uma solução de fosfato trissódico $\left(\mathrm{NA}_{3} \mathrm{PO}_{4}\right)$ a $10 \%$ por pelo menos 15 minutos ou então o tratamento térmico para sementes secas, contudo estes tratamentos ainda estão em fase de experimentos (JONES et al., 1991).

Estudos imunoquímicos sobre o TMV tem sido feitos desde a década de 70 . Trabalhos pioneiros como os de VAN REGENMORTEL \& LELARGE (1973), já demonstravam a especificidade antigênica das proteínas do TMV, realizada em ensaios de imunodifusão, imunoeletroforese e outros testes de precipitação.

Com base nestes dados, tornou-se possível utilizar o ToMV como modelo, uma vez que os estudos básicos da imunologia do TMV já foram realizados, servindo de base para se estabelecer a precisão e eficácia da produção de anticorpos monoclonais aplicados a vírus de plantas. Esta metodologia revelou-se mais específica, uma vez que soros policlonais anti ToMV ou anti TMV apresentam alta taxa de reação cruzada e a separação desses vírus pode ser feita somente através dos sintomas em planta teste de tabaco (Nicotiana sylvestris var. White Burley), onde o ToMV apresenta lesões locais, enquanto que o TMV apresenta sintomas de infecção sistêmica (CANER et al., 1990 e JONES et al., 1991).

Entre os problemas encontrados no uso de plantas indicadoras, além das instalações apropriadas, necessita-se ter o vírus purificado para a realização do teste e dispor de tempo, desde a produção 
das mudas da planta indicadora, até a visualização dos sintomas após a inoculação dos vírus, sem contar com a existência de uma estirpe do TMV que também causa lesão local. Este fato, quando se trata de estabelecer a sanidade de um lote de sementes ou o diagnóstico da doença já instalada no campo, torna-se inviável. 


\section{3 - MATERIAL E MÉTODOS}

\section{1 - Antígeno}

Os vírus ToMV e TMV foram obtidos do Instituto Biológico de São Paulo, gentilmente cedidos pela pesquisadora Addolorata Colariccio, da Seção de Virologia Fitopatológica e Fisiopatologia. Ambos os antígenos foram purificados em gradiente de cloreto de césio ( $\mathrm{ClCs}$ ), segundo a metodologia descrita por FERNANDES et al. (1983).

\section{2 - Animais}

Foram utilizados para a obtenção do soro policlonal de coelhos fêmeas Nova Zelândia brancos, provenientes da Granja da Escola Superior de Agricultura "Luiz de Queiroz" (ESALQ) - Depto. de Zootecnia de Não-Ruminantes.

Os camundongos eram fêmeas singênicas, da linhagem BALB/c, criados e mantidos no Laboratório de Biologia Celular, Universidade Federal de São Paulo ( UNIFESP). 


\section{3 - Preparo do anticorpo}

\subsection{1 - Imunização dos camundongos}

Quatro camundongos fêmeas BALB/c, de dois mêses de idade foram imunizados com $20 \mu \mathrm{g}$ de ToMV . Na primeira imunização, foram feitas injeções subcutâneas de 0,1 ml em quatro sítios diferentes, próximos às cadeias ganglionares (HURN \& CHANTLER, 1980) dos membros com Adjuvante Completo de Freund (F5881 - Sigma) e PBS na proporção de 1:3 $(\mathrm{v} / \mathrm{v})$. Na segunda imunização, realizada 30 dias após, foi utilizado Adjuvante Incompleto de Freund (F5506 - Sigma) e PBS para incorporação do imunógeno, também por via subcutânea, na proporção de 1:3 (v/v), com $10 \mu \mathrm{g}$ do imunógeno. Seguiram-se mais 3 imunizações, a intervalos de 30 dias com $15 \mu \mathrm{g}$ de imunógeno por camundongo.

Um segundo grupo de camundongos BALB/c fêmeas foi imunizado seguindo a mesma metodologia descrita acima, sendo modificado o intervalo entre as imunizações, que ao invés de 30 dias, foi de 15 dias. As diferenças na titulação dos soros foram determinadas em teste de ELISA indireto.

O fato de haver um segundo grupo de animais ocorreu devido às diversas indicações na literatura quanto ao intervalo entre as imunizações. 
A titulação dos soros dos animais foi feita através de teste indireto de ELISA e os soros foram coletados antes de cada nova imunização, do plexo ocular dos camundongos. As alíquotas de sangue coletadas eram então deixadas a $37^{\circ} \mathrm{C}$ por 1 hora, centrifugadas a $200 \mathrm{~g}$ por 2 minutos para a separação do soro.

Foi selecionado o camundongo que melhor respondeu ao esquema de imunizações, apresentando maior título em ELISA, para a realização da fusão, recebendo uma injeção intravenosa de 15 ug de imunógeno em PBS.

\subsection{2 - Imunização dos coelhos}

Três coelhos fêmeas Nova Zelândia com 2 meses de idade foram imunizadas com $20 \mu \mathrm{g}$ de ToMV em PBS, incorporados com Adjuvante Completo de Freund e PBS na proporção de 1:3 (v/v). Na primeira imunização, injeções intramusculares de $0,5 \mathrm{ml}$ foram feitas em dois sítios diferentes. Seguiram-se 3 imunizações a intervalos de 20 dias, de $15 \mu \mathrm{g}$ de ToMV em PBS, via intramuscular, em dois sítios diferentes.

A titulação dos soros foi feita da mesma maneira que os camundongos, exceto que a retirada do sangue foi feita através de corte na orelha dos animais. Testes de ELISA foram realizados a fim de se determinar qual o coelho que apresentava melhor título em D. O. a $492 \mathrm{~nm}$. 
O coelho selecionado recebeu $50 \mu$ do ToMV em PBS também por via intravenosa. Dois dias após, o coelho foi sangrado e o soro coletado por centrifugação após descanso por uma hora a $37^{\circ} \mathrm{C}$.

\section{4 - Células}

Células da linhagem SP2/OAg14 (SP2) de mieloma de camundongo, fornecidas pela UNIFESP, não secretoras de imunoglobulinas (KEARNEY et al.,1979) e resistentes à 8-aza-guanina foram utilizadas para a realização da fusão (SHULMAN et al., 1985). As culturas foram mantidas em meio RPMI 1640, contendo $10 \%$ de soro fetal bovino (R10), em atmosfera úmida de $5 \%$ de $\mathrm{CO}_{2,}$,

\section{5 - Obtenção de "Feeder Layer" de macrófagos}

O "feeder layer"de macrófagos (FDM) foi preparado 48 horas antes do uso, sendo utilizados camundongos singênicos da linhagem BALB/c. Cada camundongo foi sacrificado em éter etílico e lavado em seguida em água corrente, sendo mergulhado em solução de álcool a 70 \%

por 2 a 3 minutos; em seguida, escorreu-se o excesso de álcool e o camundongo foi fixado com auxílio de agulhas, em placa de isopor recoberta por papel de alumínio, com a face ventral para cima. 
Com uma pinça dente de rato, foi levantada a pele do animal e com uma tesoura de ponta redonda, foi realizado um pequeno corte. A partir deste corte, a tesoura foi inserida por baixo, descolando a pele do camundongo, deixando exposta a cavidade peritoneal, tendo o cuidado de não rompê-la. A pele foi presa com agulhas também.

Com uma pinça de ponta lisa, a membrana que recobre a cavidade peritoneal foi levantada e com uma tesoura de ponta fina, foi realizado um pequeno corte. Através desta abertura, uma pipeta plástica estéril contendo cerca de 2 a $3 \mathrm{ml}$ de meio RPMI-1640, foi inserida no corte e a cavidade intraperitoneal foi lavada com esse meio, sendo recolhido logo em seguida, num tubo cônico estéril de $50 \mathrm{ml}$. As células foram então contadas em câmara de Neubauer e o tubo foi centrifugado por 6 minutos a $200 \mathrm{~g}$.

O sobrenadante foi aspirado com o auxílio de uma pipeta Pasteur de vidro, estéril . A partir da contagem, foi realizada uma suspensão de células de modo a serem distribuídas de $2-4 \times 10^{3}$ macrófagos/ orifício em placas de 96 poços, $10^{4}$ macrófagos/ orifício em placas de 24 poços e, nas garrafas de $25 \mathrm{~cm}^{2}, 1-2 \times 10^{5}$ macrófagos/garrafa. Garrafas e placas contendo FDM foram empregadas no cultivo de células híbridas .

Os macrófagos foram mantidos a $37^{\circ} \mathrm{C}$ em estufa de $\mathrm{CO}_{2}$. Após 4 horas, observadas ao microscópio, os macrófagos apresentaram sinais de adesão no substrato plástico ( aparecendo na forma de "estrelas" ). 
Toda a operação foi realizada em fluxo de ar laminar e para obter cerca de 10 placas de 96 orifícios, necessárias para a fusão, foram utilizados 4 camundongos.

\section{6 - Fusão celular}

O camundongo que apresentou maior titulação através de teste de ELISA Indireto, teve seu baço retirado assepticamente sob fluxo laminar vertical e transferido para placa de Petri contendo $5 \mathrm{ml}$ de meio RPMI. Com o auxílio de pinças, foi feito o esmagamento gentil do órgão para a liberação das células. A suspensão celular foi filtrada em tela de nylon para retirada dos fragmentos grosseiros. As células foram então transferidas para tubo cônico de $50 \mathrm{ml}$, que continha $5 \times 10^{6}$ células SP2 obtidas de culturas semi-confluentes.

Foi adicionado à mistura de células, gota a gota, sob agitação leve e durante 30 segundos, $1 \mathrm{ml}$ do agente fusionante preparado previamente, contendo polietilenoglicol (PEG de PM 3000-3700, ATCC, Rockville, MD 20852, USA). Foi mantida agitação suave por um minuto. O passo seguinte compreendeu a diluição lenta da suspensão celular com meio de cultura RPMI, realizada adicionando-se, sob agitação suave, $1 \mathrm{ml}$ do meio em 30 segundos; $3 \mathrm{ml}$ do meio em 30 segundos; $16 \mathrm{ml}$ do meio por 60 segundos e finalmente, completado o volume para $50 \mathrm{ml}$. Após repouso de 5 
minutos, seguiu-se centrifugação de $200 \mathrm{~g}$ por 10 minutos. $\mathrm{O}$ sedimento foi ressuspendido em $30 \mathrm{ml}$ de meio R10 seguido de nova centrifugação.

Novamente o sedimento foi ressuspendido em meio HAT, em volume adequado para a distribuição nas placas de cultura de 96 poços (2 gotas por poço, equivalente a $100 \mu$ l de líquido), contendo "feeder layer" de macrófagos (FLM) também cultivadas em meio HAT. O FLM foi preparado dois dias antes de sua utilização, segundo método descrito ( St. GROTH \& SCHEIDEGGER , 1980 e LOPES et al. , 1982).

\section{7 - Ensaio imunoenzimático}

A titulação dos soros de camundongo e de coelho, bem como a análise dos sobrenadantes de cultura dos híbridos murinos obtidos, foram feitas numa primeira etapa, através de ensaio imunoenzimático. Resumidamente, as placas de polivinil de 96 orifícios foram sensibilizadas com ToMV ( $1 \mu \mathrm{g} / \mathrm{ml}$ ), colocando-se $50 \mu$ por poço, sendo incubadas por 1 hora a $37^{\circ} \mathrm{C}$.

Após a sensibilização, os sítios ativos remanescentes do plástico foram bloqueados com $200 \mu$ de tampão de bloqueio (TB1) por poço, por mais uma hora a $37^{\circ} \mathrm{C}$, batendo-se a placa após este período para descarte do líquido em excesso. Em seguida, sobrenadantes de cultura ou diluições dos soros de camundongo e de coelho anti-ToMV (a serem 
testados), foram adicionados às placas, nas diluições pré-estabelecidas, em duplicatas, e incubados por uma hora a $37^{\circ} \mathrm{C}$.

Para se obter a quantidade ideal de antígeno a ser colocado, bem como a diluição mais apropriada dos soros a serem testados, foram realizados diversos ELISAs, partindo de concentrações de 0,1 a 2 $\mu \mathrm{g} / \mathrm{ml}$ dos antígenos, variando a diluição dos soros de 1:100 até 1:8000, para se chegar à quantidade ideal de antígeno que reage, estabelecida em 1 $\mu \mathrm{g} / \mathrm{ml}$. A quantidade de anti-imunoglobulina de camundongo-peroxidase ("blotting grade affinity purified goat anti-mouse $\lg G(\mathrm{H}+\mathrm{L})$ human $\lg G$ adsorbed horseradish peroxidase conjugate" - Bio Rad) foi também estabelecida para 1: 2000.

Os orifícios foram então lavados com $200 \mu l$ de PBS-T-G por 3 vezes. A placa foi sêca batendo-se em papel absorvente até que o excesso de líquido fosse eliminado. A seguir, fez-se a incubação, uma hora a $37^{\circ} \mathrm{C}$, com conjugado anti-imunoglobulina IgG de camundongo-peroxidase ou ( no caso dos soros serem de camundongos) ou anti-imunoglobulina lg $G$ de coelho-peroxidase ( no caso dos soros serem de coelhos).

Após mais 3 lavagens com PBS-T-G, como descrito anteriormente, a reação foi revelada com orto-fenilenodiamina (OPD) contendo $\mathrm{H}_{2} \mathrm{O}_{2}$, diluído em tampão de $\mathrm{OPD}$, no escuro por 2 a 3 minutos, quando foi bloqueada com solução "stopper "de OPD, procedendo-se a leitura em leitor de placa de ELISA, a $492 \mathrm{~nm}$. Os ensaios foram realizados 
com o vírus TMV, da mesma forma descrita acima, para se testar o nível de reações cruzadas que os soros apresentam.

\section{8 - Congelamento e descongelamento de células}

O congelamento de hibridomas foi feito em alíquotas de 1 $\mathrm{ml}$ contendo $0,5 \mathrm{ml}$ de meio de congelamento mais $0,5 \mathrm{ml}$ da suspensão de células contendo $4 \times 10^{6}$ células, obtendo uma concentração final de $2 \times 10^{6}$ células por $\mathrm{ml}$, estocadas por 24 horas à $-70^{\circ} \mathrm{C}$ antes de serem transferidas para botijões contendo nitrogênio líquido.

O descongelamento de células de mieloma foi efetuado em banho-maria a $37^{\circ} \mathrm{C}$, transferindo-se imediatamente para tubos de centrifuga e diluindo-se gota a gota em $9 \mathrm{ml}$ de meio R10. As células foram mantidas em repouso por 5 minutos e centrifugadas à $200 \mathrm{~g}$ por 6 minutos. Após 0 descarte do sobrenadante, as células foram ressuspendidas em $1 \mathrm{ml}$ de meio $\mathrm{R} 10$ e transferidas para garrafas de cultura de $25 \mathrm{~cm}^{2}$ contendo $4 \mathrm{ml}$ de meio R10 fresco.

As células foram então cultivadas em meio R10, a $37^{\circ} \mathrm{C}$, em estufa automática (Forma Scientific) mantenedora de atmosfera de 95\% de umidade e $5 \%$ de $\mathrm{CO}_{2}$.

Para a expansão de linhagens celulares aderentes, culturas confluentes foram descoladas batendo-se levemente com a palma da mão ao fundo da garrafa. No caso dos hibridomas e das células de 
mieloma para a fusão, a remoção foi feita através de raspagem das culturas com "cell scrapers".

\section{9 - Clonagem dos melhores híbridos}

Transcorridos 10 dias da fusão, nos orifícios das 10 placas, foi observado crescimento de colônias de hibridomas. Tais colônias, denominadas "mães" foram submetidas a um "screening", ou seja, um rastreamento para seleção das melhores "mães" secretoras de anticorpos através de um ELISA indireto, da mesma forma descrita acima, utilizando como soro $50 \mu l$ do sobrenadante dos orifícios que apresentaram crescimento.

Para a realização da clonagem, cada "mãe" separadamente foi submetida a uma contagem de células e ressuspendida em meio R10 a fim de se obter 100 a 150 células em $6 \mathrm{ml}$ (volume necessário para se colocar uma gota em cada orifício da placa de cultura de 96 orifícios), deste modo, cada gota deveria conter aproximadamente uma célula, que ao crescer seria um só clone. Desta forma, tivemos novamente 6 placas de 96 orifícios, que após 10 dias foram submetidas a um novo rastreamento e seleção, pelo teste indireto de ELISA.

Após a seleção dos clones, foi realizado um crescimento em placa de 24 orifícios e as células de cada cultura foram passadas para camundongos previamente injetados com 0,5 $\mathrm{ml}$ de óleo mineral Pristane 
$(2,6,10,14$-tetramethylpentadecane, Sigma, cat. P 1403) 48 horas antes de receber as células. Transcorridos 10 dias, o líquido ascítico foi retirado ascepticamente, centrifugado e o "pellet" foi ressuspendido em meio R10 e colocado em garrafas de $25 \mathrm{~cm}^{2}$ para crescimento em estufa incubadora de $\mathrm{CO}_{2}$, a $37{ }^{\circ} \mathrm{C}$. Após 6 dias, houve crescimento dos clones $8 \mathrm{G} 7 \mathrm{G} 2,8 \mathrm{C} 12 \mathrm{~F} 5 \mathrm{e}$ 10H9F9, e esses foram expandidos para garrafas de $75 \mathrm{~cm}^{2}$, com meio R10 e depois de 10 dias, uma alíquota do sobrenadante foi retirada e testada em ELISA, utilizando $50 \mu$ l por orifício.

\subsection{0 - Marcação dos soros de coelho}

\subsection{1 - Purificação de soro de coelho anti-ToMV em Proteína A}

O soro de coelho foi purificado em uma coluna de sefarose-proteína A ( Affi-gel protein A agarose, Bio-Rad, cat. no. 153-6153) segundo o procedimento abaixo (OI \& HEZENBERG, 1980): a coluna, preparada com $5 \mathrm{~cm}$, foi lavada com $100 \mathrm{ml}$ de uma solução de Tris- $\mathrm{HCl}$, pulsionada por bomba peristáltica. O soro foi preparado, antes de passar na coluna, adicionando-se para cada $1,5 \mathrm{ml}$ de soro, $4 \mathrm{ml}$ da solução de Tris- $\mathrm{NaCl}$ e filtrado em membrana millipore de 0,22 $\mu \mathrm{m}$.

Em sistema fechado, $5,5 \mathrm{ml}$ da solução contendo o soro foi passado, por duas horas pela bomba peristáltica. Após este período, a coluna foi lavada com $100 \mathrm{ml}$ de tampão Tris- $\mathrm{NaCl}$ para a remoção das 
impurezas contidas no soro, ficando retidos na coluna, apenas imunoglobulinas do tipo $\lg G$.

O eluato foi então recolhido passando-se em tampão Glicina- $\mathrm{NaCl}$, em alíquotas de $2 \mathrm{ml}$ em 10 tubos contendo $50 \mu \mathrm{l}$ do tampão Tris- $\mathrm{HCl}$. O tubo controle recebeu $50 \mu \mathrm{l}$ do tampão Tris- $\mathrm{HCl}$ mais $2 \mathrm{ml}$ de tampão Glicina.

De cada tubo foi retirada uma alíquota de $20 \mu \mathrm{l}$ para realização do teste de quantificação proteica (BRADFORD, 1978), utilizado como indicador, ou seja, como um teste qualitativo. Este teste foi realizado colocando-se os $20 \mu$ l de cada tubo mais $200 \mu l$ do reagente Coomassie-blue em placa de 96 orifícios. Os tubos correspondentes às amostras dos orifícios que adiquiriram coloração azul, foram separadas e submetidas a uma diálise, em membrana de celulose, em 1 litro de tampão PBS, por uma noite a $5{ }^{\circ} \mathrm{C}$, sob agitação.

Após este período, a solução de PBS foi trocada e a diálise continuou por mais 3 horas. As amostras foram então colocadas em tubos estéreis e lidas em espectrofotômetro a $280 \mathrm{~nm}$, onde a relação D.O./mg de $\lg$ foi de 1,3:1. As amostras foram aliquotadas em $1 \mathrm{mg} / \mathrm{ml}$ de $\lg \mathrm{g}$ do soro.

\subsection{2 - Acoplamento dos anticorpos com Biotina}

Os anticorpos obtidos do soro de coelho purificado em proteína-A, na concentração de $1 \mathrm{mg} / \mathrm{ml}$, foram submetidos a uma diálise em 
4 I de tampão borato, por uma noite segundo a metodologia descrita por WOFSY (1983).

Após este período, $4 \mathrm{ml}$ da solução contendo os anticorpos foram retirados da membrana e foram adicionados $80 \mu l$ de $\mathrm{N}$-Hydroxysuccinimidobiotin (BOSU) para cada $\mathrm{ml}$ de anticorpo dialisado e deixado sob agitação a temperatura ambiente, por 4 horas. Em seguida, a mistura foi submetida a nova diálise em 1 litro de PBS, novamente durante 12 horas. Aos anticorpos marcados foram acondicionados em alíquotas de 1 $\mathrm{ml}$ contendo $0,2 \%$ de glicerol.

\subsection{3 - Acoplamento dos anticorpos com Peroxidase}

O acoplamento com peroxidase foi realizado segundo a metodologia descrita por AVRAMEAS et al. (1978) e AVRAMEAS (1979). A peroxidase foi preparada dissolvendo-se $10 \mathrm{mg}$ de HRP ( Horseradishperoxidase) em $0,2 \mathrm{ml}$ de glutaraldeído $25 \% \mathrm{p} / \mathrm{v}$ em $10 \mathrm{mM}$ de fosfato de sódio a pH 6,8, para cada $1 \mathrm{mg}$ de IgG anti-ToMV, proveniente da purificação em proteína A. Após 18 horas à temperatura ambiente, o glutaraldeído livre foi removido por filtração em coluna Sephadex G-25 (Pharmacia, cat. no. 17-0572-01) de $5 \mathrm{ml}$.

A coluna foi lavada previamente com $50 \mathrm{ml}$ de $\mathrm{NaCl}$ 0,15 M. Após colocar o HRP - glutaraldeído na coluna, foi adicionado cuidadosamente a solução $0,15 \mathrm{M}$ de $\mathrm{NaCl}$. 
As frações de tonalidade castanha foram coletadas e colocadas para dialisar em $500 \mathrm{ml}$ de tampão carbonato-bicarbonato de

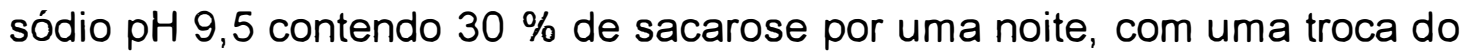
tampão, após 3 horas.

À solução acima, foi adicionado $0,1 \mathrm{ml}$ de anticorpo de coelho anti-ToMV purificado em proteína-A e concentrado em sistema Amicom para $5 \mathrm{mg} / \mathrm{ml}$. A mistura foi dialisada em 1 litro de tampão carbonato-bicarbonato $\mathrm{pH} 9,5$ por 24 horas a $4{ }^{\circ} \mathrm{C}$. Após este período, foi adicionado $0,1 \mathrm{ml}$ de ethanolamina $0,2 \mathrm{M}, \mathrm{pH} 7,0$, incubado a $4{ }^{\circ} \mathrm{C}$ por 4 horas. Os anticorpos marcados foram então retirados e acondicionados em alíquotas de $1 \mathrm{ml} \mathrm{com} 50 \%$ de glicerol.

Os dois anticorpos marcados foram testados em ensaio de ELISA contra os vírus TMV e ToMV.

\subsection{1 - Ensaio imunoenzimático quantitativo}

Placas de poliestireno foram sensibilizadas segundo a metodologia descrita por SCHECHTER \& LOPES (1990), com $10 \mu \mathrm{g} / \mathrm{ml}$ de soro de coelho anti-ToMV purificado por afinidade em coluna de proteína A, em PBS (50 $\mu$ / /orifício) por 1 hora a $37^{\circ} \mathrm{C}$. Em seguida, os sítios ativos remanescentes do plástico foram bloqueados com $200 \mu$ l PBS contendo $1 \%$ de soro albumina bovina por uma hora a $37^{\circ} \mathrm{C}$. 
O ToMV purificado foi diluído em PBS, em diferentes concentrações $(0,1 \mu \mathrm{g} / \mathrm{ml} ; 1 \mu \mathrm{g} / \mathrm{ml} ; 10 \mu \mathrm{g} / \mathrm{ml}$ e $100 \mu \mathrm{g} / \mathrm{ml})$, e foram adicionados $50 \mu$ à placa para incubação por uma hora a $37^{\circ} \mathrm{C} .50 \mu \mathrm{l}$ de sobrenadantes de cultura dos anticorpos monoclonais obtidos anti-ToMV foram testados em triplicatas, e incubados por uma hora a $37^{\circ} \mathrm{C}$. Os orifícios foram então, lavados com $200 \mu \mathrm{l}$ de PBS-T-G, seguido de incubação, uma hora à $37^{\circ} \mathrm{C}$, com $50 \mu \mathrm{l}$ de conjugado anti-imunoglobulina de camundongo-peroxidase (EIA grade affinity purified goat anti-mouse IgG $(H+L)$ horseradish peroxidase conjugate - Bio Rad) diluído 1:200. Após lavagens, com PBS-T-G, a reação foi revelada com OPD na concentração de $0,05 \mathrm{mg} / \mathrm{ml}$ de tampão de OPD.

\subsection{2 - Isotipagem dos anticorpos monoclonais}

Para a isotipagem dos anticorpos monoclonais foi utilizado um "kit Immuno Select" (monoclonal antibody-based isotyping system for mouse immunoglobulins - Gibco BRL - cat. no. 9660SA), seguindo as especificações do fabricante, abaixo discriminadas.

Uma placa de poliestireno de 96 orifícios foi sensibilizada com $50 \mu$ l/orifício dos 8 isotipos anti-mouse diluidos em tampão de diluição (IgG1, IgG2a, IgG2b, IgM, IgA, Kappa e Lambda) e incubados por uma hora à temperatura ambiente. Os orifícios foram então bloqueados com $150 \mu \mathrm{l}$ de tampão de bloqueio por 15 minutos, à temperatura ambiente. Após este 
tempo, os orifícios foram lavados com tampão de lavagem três vezes e então foram acrescentados, a cada isotipo, $50 \mu$ do controle negativo , $50 \mu l$ do controle positivo e $50 \mu \mathrm{l}$ de sobrenadante de cada anticorpo monoclonal a ser testado, incubado por uma hora à temperatura ambiente.

Em seguida, fez-se nova lavagem ( 3 vezes) com o tampão de lavagem e foram adicionados $50 \mu$ lorifício do conjugado anti-lgG de camundongo marcado com fostatase alcalina e incubado por mais uma hora a temperatura ambiente. Após este tempo, fez-se nova lavagem, como descrita anteriormente, e foram adicionados $50 \mu$ l /orifício da Solução Substrato (10\% de diethilalamina ( $\mathrm{pH} 9,8), 0,5 \mathrm{mM}$ de $\mathrm{MgCl}_{2}, 0,02 \%$ de $\mathrm{NaN}_{3}$ mais pNPP ( $p$-nitrofenilfosfato)) e incubado a $37^{\circ} \mathrm{C}$ por 30 minutos no escuro, quando os orifícios apresentaram-se amarelados e foi realizada a leitura em leitor de placa de ELISA a $405 \mathrm{~nm}$.

\subsection{3 - Soluções utilizadas}

PBS

$-8 \mathrm{~g}$ de $\mathrm{NaCl}$

$-0,2 \mathrm{~g}$ de $\mathrm{KCl}$

$-1,15 \mathrm{~g}$ de $\mathrm{Na}_{2} \mathrm{HPO}_{4}$

$-0,2 \mathrm{~g}$ de $\mathrm{KH}_{2} \mathrm{PO}_{4}$

$\mathrm{O}$ volume foi completado para 1 litro com água destilada, e o pH acertado para 7,36 . 
Tampão de Bloqueio - TB1

- PBS

- $1 \%$ de BSA ( Soro Albumina Bovina)

Tampão PBS-T-G

- PBS

$-0,05 \%$ de Tween 20

$-0,25 \%$ de gelatina

Tampão de OPD

- 12,15 ml de ácido cítrico 0,4 M

$-25,7 \mathrm{ml}$ de $\mathrm{Na}_{2} \mathrm{PO}_{4} \mathrm{O}, 4 \mathrm{M}$

- 300 ul de $\mathrm{H}_{2} \mathrm{O}_{2} 30$ vol.

O volume foi completado para $200 \mathrm{ml}$ com água destilada e o $\mathrm{pH}$ foi acertado para 5,3 , ficando armazenado no escuro a $5^{\circ} \mathrm{C}$.

"STOPPER" para OPD

$-\mathrm{H}_{2} \mathrm{SO}_{4} 4 \mathrm{~N}$

$-0,5 \%$ de $\mathrm{Na}_{2} \mathrm{SO}_{3}$

Tampão Tris- $\mathrm{NaCl}$

- Trizma Base 0,05 M

- $\mathrm{NaCl} 0,15 \mathrm{M}$

Acertado o pH para 8,2. 
Tampão Tris- $\mathrm{HCl}$

- Trizma Base $1 \mathrm{M}$

Acertado o $\mathrm{pH}$ para $9,0 \mathrm{com} \mathrm{HCl}$.

Tampão Glicina

- Glicina $50 \mathrm{mM}$

$-\mathrm{NaCl} 0,15 \mathrm{M}$

Acertado o $\mathrm{pH}$ para 3,0.

CBB

- 8 mg de Coomassie Brilhant Blue PBG 250

$-5 \mathrm{ml}$ de etanol

- $10 \mathrm{ml}$ de ácido orto-fosfórico $\left(\mathrm{H}_{3} \mathrm{PO}_{4}\right)$ concentrado

O volume foi completado para $100 \mathrm{ml}$ com água deionizada, a solução foi filtrada e armazenada no escuro.

Tampão Borato

- ácido bórico 0,2M

$\mathrm{O}$ pH foi acertado para 8,5 com ácido bórico.

BOSU

- $1 \mathrm{mg}$ de BOSU (N-Hydroxysuccinimidobiotin - Sigma)

$-1 \mathrm{ml}$ de DMSO (Dimetil sulfoxido) 


\section{Tampão Fosfato}

- solução "A": 0,2 M de fosfato de sódio monobásico

- solução "B": 0,2 M de fosfato de sódio dibásico

Foi adicionado $51 \mathrm{ml}$ da solução "A" e $49 \mathrm{ml}$ da solução "B", completado o volume para $200 \mathrm{ml}$ com água destilada.

Tampão Carbonato-Bicarbonato

- solução "A": 0,2 $\mathrm{M}$ de carbonato de sódio anidro $\left(\mathrm{Na}_{2} \mathrm{CO}_{3}\right)$

- solução "B": 0,2 M de carbonato hidrogênio de sódio $\left(\mathrm{NaHCO}_{3}\right)$

Foi adicionado $7,5 \mathrm{ml}$ da solução "A"e $42,5 \mathrm{ml}$ da solução "B" e completado o volume para $200 \mathrm{ml}$ com água destilada.

TBS

- 6,06 g de Trizma-base ( $50 \mathrm{mM}$ )

$-11,7 \mathrm{~g}$ de $\mathrm{Na} \mathrm{Cl}(200 \mathrm{mM})$

$\mathrm{O} \mathrm{pH}$ foi acertado para 7,5 com ácido clorídrico e o volume completado para 1 litro com água destilada.

Tampão de Diluição

$-35 \mathrm{ml}$ de TBS

- $35 \mathrm{mg}$ de azida sódica $\left(\mathrm{Na} \mathrm{N}_{3}\right)$

Tampão de Bloqueio - TB 2

- $17 \mathrm{ml}$ de TBS

$-0,17 \mathrm{~g}$ de soro albumina bovina (BSA)

Tampão de Lavagem 
$-100 \mathrm{ml}$ de TBS

$-50 \mu$ de tween 20

\title{
3.14 - Meios de cultura utilizados
}

\author{
Meio Básico RPMI - 1640
}

O meio RPMI-1640 (sem bicarbonato, contendo L-glutamina) (1 pacote por litro) foi dissolvido em água mili-Q, acrescentando: $-2,0 \mathrm{~g}$ de $\mathrm{NaHCO}_{3}$

$-5,96 \mathrm{~g}$ de HEPES (p.m. 238,3)

- $40 \mathrm{mg}$ de gentamicina

- $\beta$ - mercaptanol na concentração final de $5 \times 10^{-5} \mathrm{M}$.

$\mathrm{O} \mathrm{pH}$ foi ajustado para $7,2-7,4 \mathrm{com} \mathrm{HCl}$ ou $\mathrm{NaOH}$ e 0 volume foi completado para 1 litro. $O$ meio foi filtrado em um sistema Millipore (filtro de 0,22 mm) para esterilização, utilizando vácuo de 5 psi.

Meio R10

- $10 \mathrm{ml}$ de soro fetal bovino ( SFB)

- $90 \mathrm{ml}$ de RPMI-1640

O SFB foi previamente inativado por 30 minutos a $56^{\circ} \mathrm{C}$ e fracionado em alíquotas de $50 \mathrm{ml}$, sendo conservado em freezer $-20^{\circ} \mathrm{C}$.

Preparo do PEG

O PEG ( Polyethilenoglycol - p.m. 3000 - 3700) foi colocado em banho-maria a $56^{\circ} \mathrm{C}$, até que se tornasse totalmente liquefeito. Com uma seringa estéril foram adicionados $2 \mathrm{ml}$ de RPMI-1640 e $200 \mu \mathrm{l}$ de 
DMSO. Esta mistura foi deixada a $37^{\circ} \mathrm{C}$ e antes de sua utilização, foi checado $\circ \mathrm{pH}$ da solução resultante (que deve estar entre 7,0 e 7,5) A solução de PEG foi então aliquotada em tubos eppendorf contendo $1 \mathrm{ml}$ da solução.

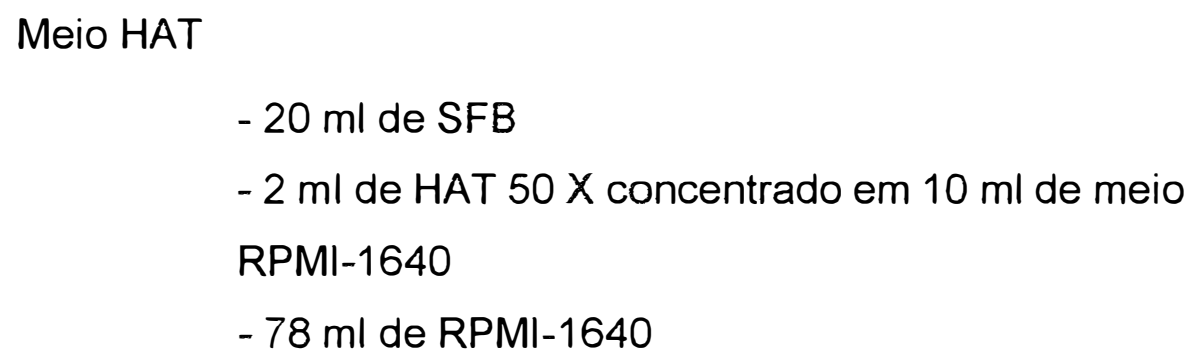

Meio de Congelamento

$-4 \mathrm{ml}$ de SFB

- $4 \mathrm{ml}$ de RPMI-1640

$-2 \mathrm{ml}$ de DMSO

Meio HT 20\%

- $2 \mathrm{ml}$ de HT $50 \times$ concentrado em $10 \mathrm{ml}$ de RPMI-1640

$-20 \mathrm{ml}$ de soro fetal bovino

$-178 \mathrm{ml}$ de RPMI-1640 


\section{4 - RESULTADOS E DISCUSSÃO}

\section{1 - Intervalo entre imunizações}

De cada lote de fêmeas de camundongos BALB/C

imunizadas, foi escolhida a que apresentou melhor título, após a quarta imunização, mostrado na tabela 1, figura 1.

Segundo a tabela 1, temos uma média de aumento de D.O. de aproximadamente $60,7 \%$ quando passamos de intervalos de imunização de 15 dias para 30 dias quando se trata do vírus ToMV e 106,45 \% quando se trata do vírus TMV,embora quando comparamos a porcentagem de reação cruzada entre os vírus ToMV e TMV, temos que para 15 dias de intervalo entre imunizações, a média é de $116,0 \%$ de aumento entre as D.O. do ToMV em relação ao TMV, enquanto que para os intervalos de 30 dias entre as imunizações, este aumento de D.O. é de apenas $66,7 \%$ na média das quatro diluições. 
Tabela 1- ELISA realizado com antissoro retirado das duas melhores fêmeas de camundongos imunizadas com ToMV. Dados expressos em Densidade Ótica (D.O.) a 492 nm, após a última imunização. Na tabela, os números 1 e 2 representam, respectivamente, intervalo de 15 e 30 dias. As letras "a" e "b" - camundongo imunizado com ToMV em ELISA sensibilizado com TMV; "c" e "d" - camundongo imunizado com ToMV em ELISA sensibilizado com ToMV.

\begin{tabular}{cccccc}
\hline & & \multicolumn{2}{c}{ TMV } & \multicolumn{2}{c}{ TOMV } \\
\cline { 3 - 6 } DILUIÇÃO & CA & CA & CA & CA & CA \\
& NORMAL & INTER1a & INTER2b & INTER1C & INTER2d \\
\hline \multirow{2}{*}{$1: 400$} & 0,064 & 0,385 & 0,909 & 0,628 & 1,329 \\
$1: 800$ & 0,052 & 0,307 & 0,711 & 0,601 & 1,106 \\
& & & & & \\
$1: 1600$ & 0,055 & 0,231 & 0,492 & 0,551 & 0,631 \\
& & & & & \\
$1: 3200$ & 0,064 & 0,175 & 0,254 & 0,472 & 0,601 \\
\hline
\end{tabular}




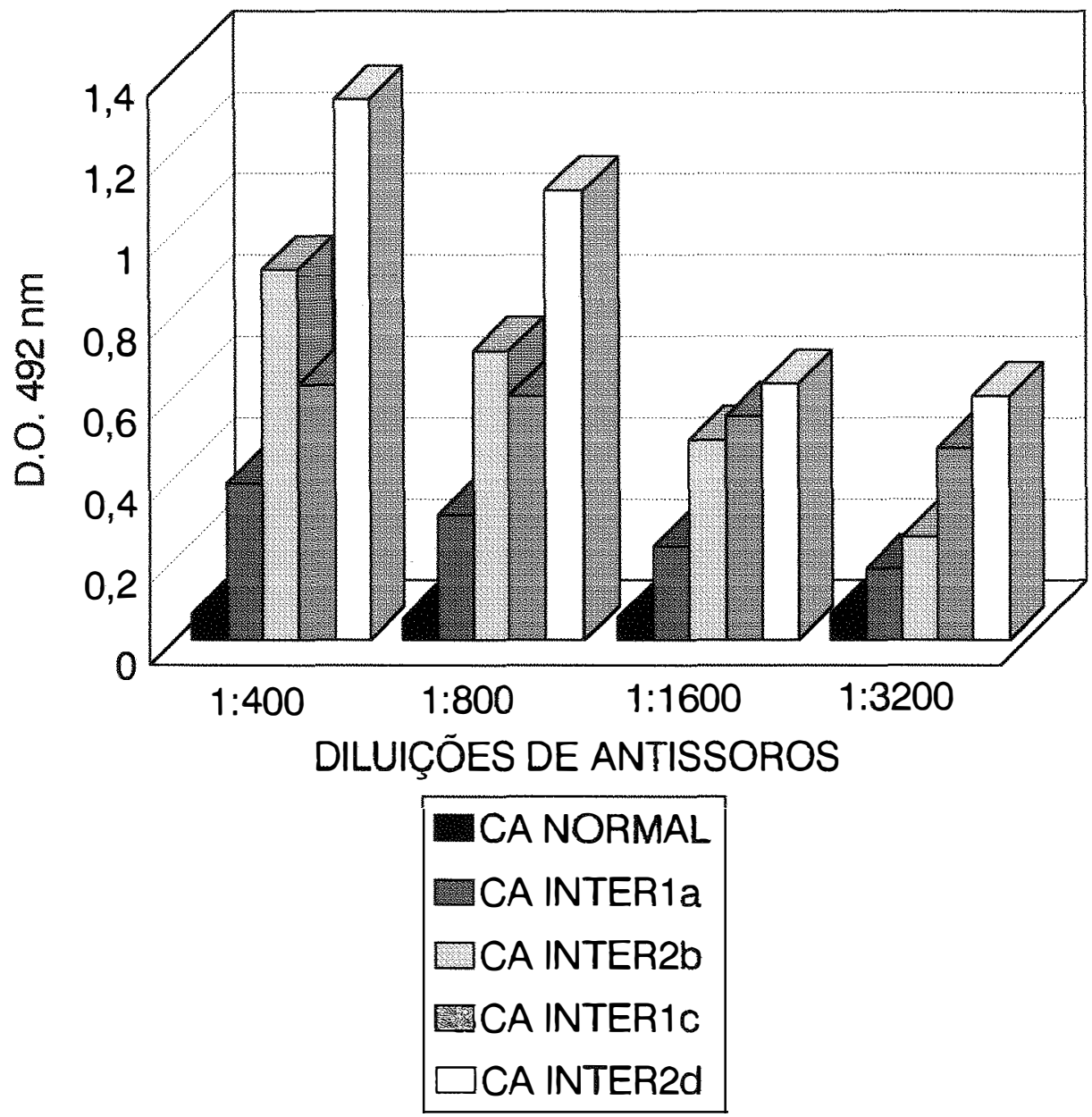

Figura 1 - Diferenças de D.O. observadas entre antissoros obtidos de camundongos (CA) de lotes diferentes que foram imunizados com ToMV a intervalos de 15 e 30 dias (números 1 e 2, respectivamente), em placas sensibilizadas com TMV (letras "a" e "b") e em placas sensibilizadas com ToMV (letras "c"e "d"). 
Os dados da tabela 1 mostram que para o ToMV, o intervalo ideal entre imunizações é de 30 dias, quando comparado a intervalos de 15 dias, onde se obtém uma reposta muito melhor da titulação dos soros policlonais.

\section{Segundo YEWDELL \& GERHARD (1981), a alta} porcentagem de reação cruzada, para o caso de anticorpos produzidos contra uma proteína viral, mostra uma relação epitópica, o que não significa, contudo, que anticorpos que reajam cruzado compartilhem de funções comuns ou origem genética comum.

Embora não haja trabalhos com este vírus, indicando qual o melhor tempo entre as imunizações, houve a necessidade de serem realizados experimentos, já que os autores discordam entre sí e diversos intervalos entre as imunizações são citados.

Neste trabalho, mostramos que com 30 dias de intervalo entre as imunizações os títulos obtidos foram melhores que os obtidos a intervalos de 15 dias e a porcentagem de reação cruzada com o vírus TMV permaneceu em níveis baixos.

O fato que o TMV apresentou títulos de reação cruzada mais baixos quando as imunizações foram realizadas a intervalos de 15 dias pode ser explicado devido a maior exposição do camundongo a epitopos comuns do ToMV e TMV, resultando numa resposta maior ao TMV quando a intervalos mais prolongados, ou ainda a imunogenicidade diferente de 
ambos os vírus. Com este experimento observamos que há a necessidade de se determinar o tempo ideal entre as imunizações para cada antígeno, pois cada grupo de antígenos provoca uma resposta a nível de produção de anticorpos mais ou menos rápida.

\section{2 - Camundongo para a fusão}

Foram realizados testes de ELISA duplos, ou seja, com ambos os vírus TMV e ToMV, após cada imunização realizada a intervalos de 30 dias, a fim de acompanhar o desenvolvimento da curva de titulação e assim escolher o melhor camundongo para a fusão.

Os dados do teste de ELISA para os antissoros dos camundongos, para escolha do camundongo da fusão estão na tabela 2 , mostrando somente o ELISA realizado com a placa sensibilizada com ToMV.

Na Figura 2, foram exemplificadas as curvas de Densidade Ótica a $492 \mathrm{~nm}$, dos quatro camundongos, referente à titulação após a terceira imunização. Por esta Figura, podemos observar que o camundongo 3 é o que apresenta melhor curva, ou seja, a curva acompanha as diluições de maneira suave e sempre com os títulos um pouco acima dos outros camundongos. 


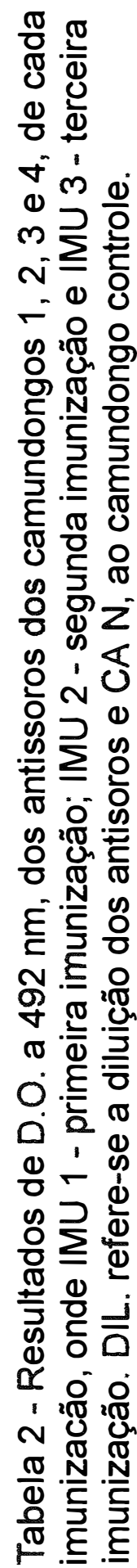

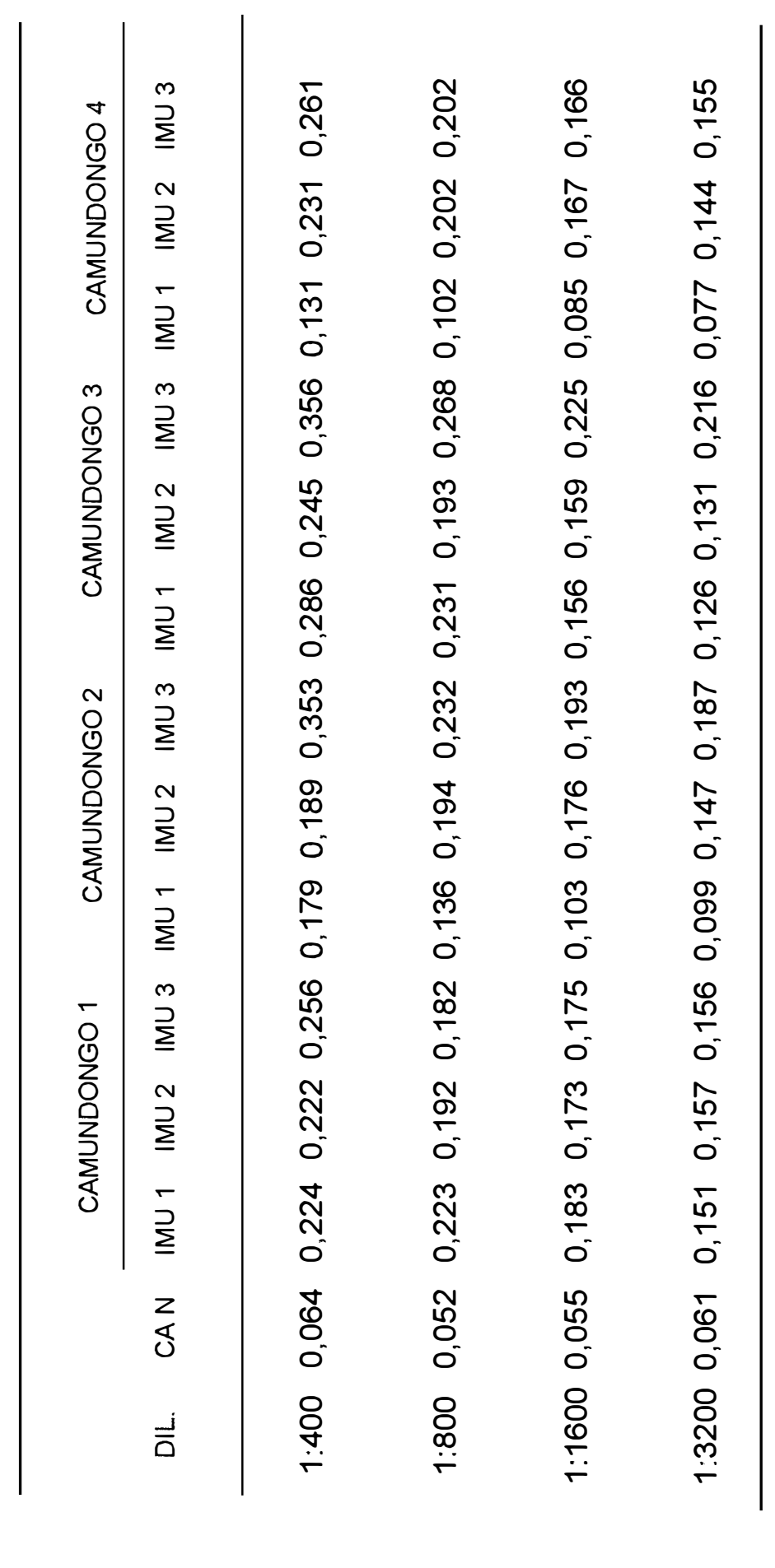




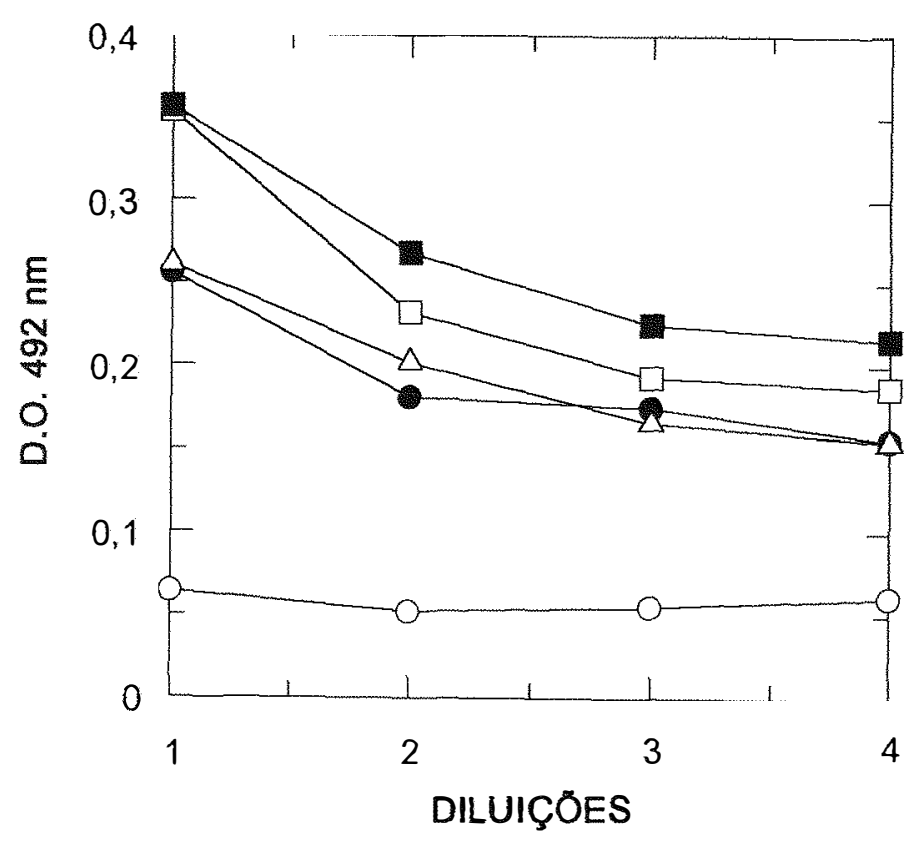

$$
\begin{aligned}
& - \text { CA NORMAL } \\
& - \text { CA } 1 \\
& - \text { CA } 2 \\
& - \text { CA } 3 \\
& \triangle \text { CA } 4
\end{aligned}
$$

Figura 2 - Curvas representando os resultados em D.O. a 492 nm, dos antissoros dos camundongos 1, 2, 3 e 4, referentes à quarta imunização, onde CA NORMAL refere-se ao camundongo controle,que não foi imunizado; CA 1, camundongo 1; CA 2, camundongo 2; CA 3, camundongo 3 e CA 4, camundongo 4. As diluições 1, 2, 3 e 4 representam respectivamente 1:400, 1:800, 1:1600 e 1:3200. 
Uma vez escolhido o camundongo C3 que apresentou maior título em D.O. a $492 \mathrm{~nm}$, um novo teste de ELISA foi realizado com o camoundongo 3 , com os diversos soros do camundongo escolhido, em placa de ELISA sensibilizada com o TMV e o TOMV, e os resultados estão demonstrados na tabela 3.

Tabela 3 - Resultado de D.O. a $492 \mathrm{~nm}$ dos antissoros do camundongo escolhido para a fusão (CA 3) testado em ELISA sensibilizado com ToMV (A) e $\operatorname{TMV}(B)$, respectivamente.

A

\begin{tabular}{cccccc} 
DILUIÇÓES & $\begin{array}{c}\text { C.NORMAL } \\
\text { TOMV }\end{array}$ & $\begin{array}{c}\text { C3SORO1 } \\
\text { TOMV }\end{array}$ & $\begin{array}{c}\text { C3SORO2 } \\
\text { TOMV }\end{array}$ & $\begin{array}{c}\text { C3SORO3 } \\
\text { TOMV }\end{array}$ & $\begin{array}{c}\text { C3SORO4 } \\
\text { TOMV }\end{array}$ \\
\hline $1: 100$ & 0,038 & 0,111 & 0,145 & 0,152 & 0,158 \\
$1: 200$ & 0,035 & 0,091 & 0,142 & 0,135 & 0,156 \\
$1: 400$ & 0,033 & 0,085 & 0,121 & 0,132 & 0,154 \\
$1: 800$ & 0,033 & 0,087 & 0,121 & 0,131 & 0,129
\end{tabular}


B

\begin{tabular}{cccccc} 
DILUIÇÕES & $\begin{array}{c}\text { C.NORMAL. } \\
\text { TMV }\end{array}$ & $\begin{array}{c}\text { C3 SORO1 } \\
\text { TMV }\end{array}$ & $\begin{array}{c}\text { C3 SORO2 } \\
\text { TMN }\end{array}$ & $\begin{array}{c}\text { C3 SORO3 } \\
\text { TMN }\end{array}$ & $\begin{array}{c}\text { C3 SORO4 } \\
\text { TMN }\end{array}$ \\
\hline $1: 100$ & 0,048 & 0,106 & 0,132 & 0,123 & 0,153 \\
$1: 200$ & 0,035 & 0,081 & 0,131 & 0,102 & 0,104 \\
$1: 400$ & 0,033 & 0,072 & 0,122 & 0,094 & 0,102 \\
$1: 800$ & 0,029 & 0,072 & 0,108 & 0,081 & 0,082
\end{tabular}

\section{3 - Resultado do antissoro policlonal de camundongo contra o}

\section{TOMV}

Como podemos observar nas Figuras 3 e 4, não é possivel se fazer uma diferenciação do TMV e ToMV, utilizando soros policlonais, mesmo sendo do melhor camundongo do lote imunizado, onde a diferença de titulação, em D.O. a $492 \mathrm{~nm}$, foi de apenas 0,008 após a última imunização, na diluição de 1:100, o que pode ser considerado um só resultado, ou seja, praticamente $100 \%$ de reação cruzada, sem nenhum reconhecimento específico para o ToMV, vírus com o qual foram feitas as imunizações. O mesmo aconteceu com o soro policlonal obtido a partir de coelho imunizado com o ToMV (Figura 5). 


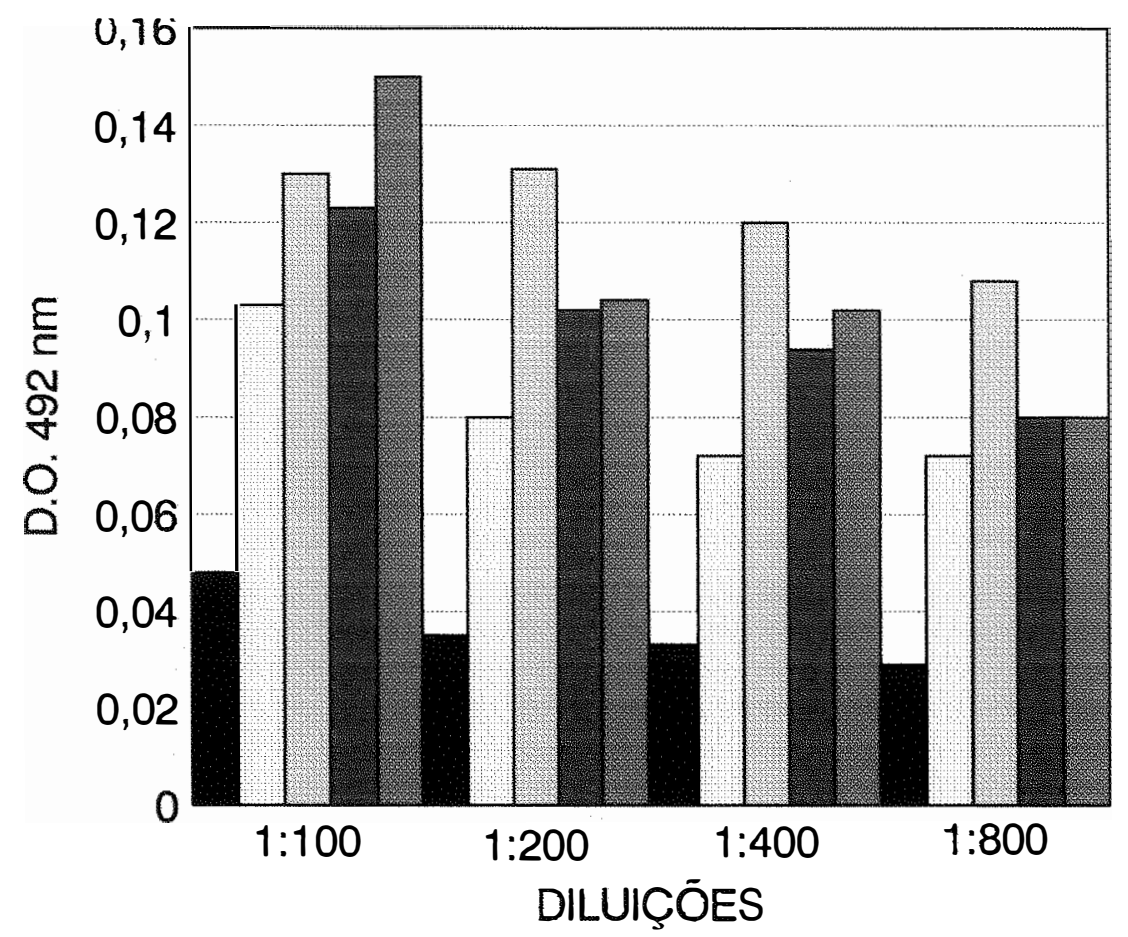
C. NORMAL. TMV
$\square$ C3 SORO1 TMV
$\square \mathrm{C} 3 \mathrm{SORO} 2 \mathrm{TMV}$
C3 SORO3 TMV
C3 SORO4 TMV

Figura 3 - Titulação dos antissoros do camundongo 3, imunizado com ToMV em teste de ELISA sensibilizado com TMV, onde C3 SORO1, corresponde ao antissoro do camundongo 3 após a primeira imunização, da mesma forma até chegar a $\mathrm{C} 3 \mathrm{SORO} 4$, correspondente ao camundongo 3 após a quarta imunização. 


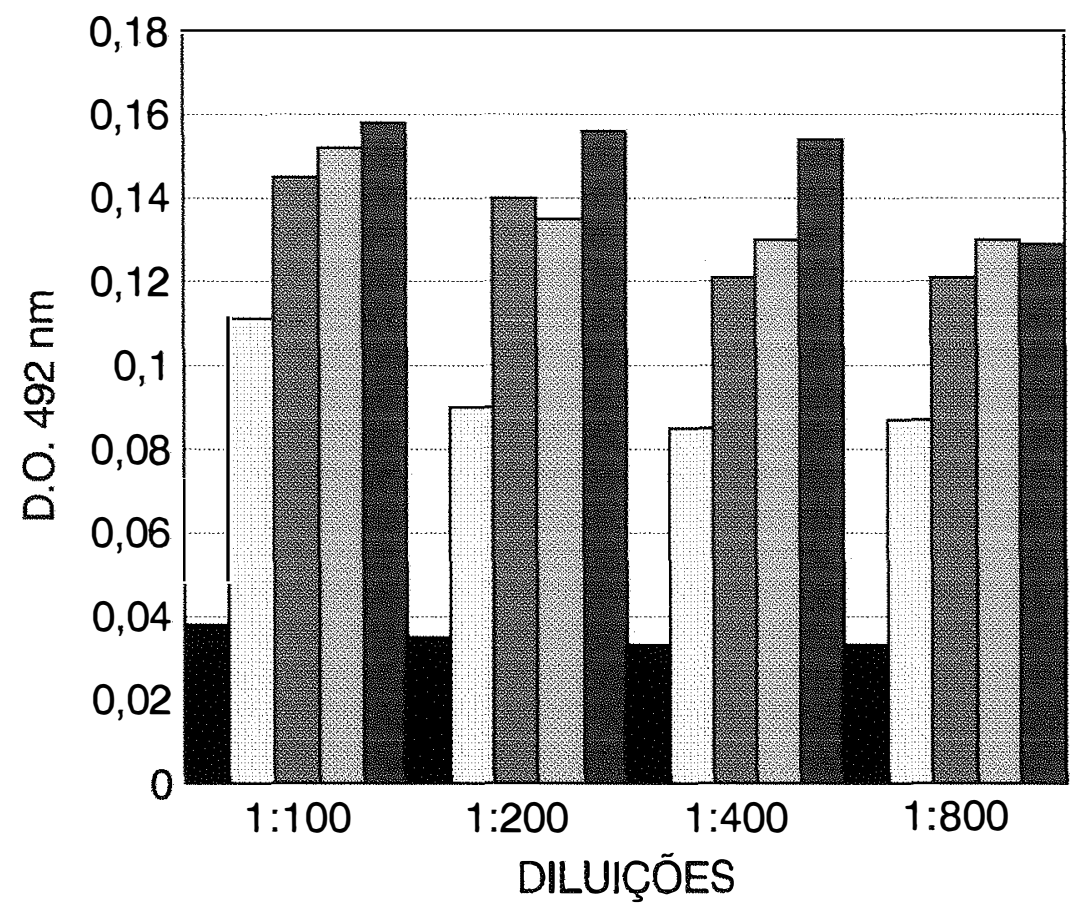

\begin{tabular}{|l}
$\square$ C.NORMAL TOMV \\
$\square$ C3 SORO1 TOMV \\
C3 SORO2 TOMV \\
C3 SORO3 TOMV \\
C3 SORO4 TOMV
\end{tabular}

Figura 4 - Titulação dos antissoros do camundongo 3, imunizado com ToMV em teste de ELISA sensibilizado com ToMV, onde C3 SORO1, corresponde ao antissoro do camundongo 3 após a primeira imunização, da mesma forma até chegar a C3 SORO4, correspondente ao camundongo 3 após a quarta imunização. 
As informações contidas nas Figuras 3 e 4 mostram 0 acompanhamento, durante as imunizações dos camundongos, da reação cruzada apresentada com o TMV e, tendo em mãos este resultado, pode-se partir para uma fusão de hibridomas com a finalidade de obter anticorpos monoclonais capazes de reconhecerem somente o ToMV.

\section{4 - Antissoros de coelho contra o ToMV}

A imunização dos coelhos foi realizada em paralelo com as imunizações dos camundongos, com o intuito, primeiro de se ter um antissoro policlonal contra o ToMV em grande quantidade, caso os antissoros policlonais de camundongo fossem capazes de diferenciar o ToMV do TMV, o que não foi possível, e mais uma vez pode ser

exemplificado na Figura 5, onde foram testados os antissoros de coelho referentes à última imunização com o ToMV, em placa de ELISA sensibilisada com TMV e com ToMV.

Nesta Figura 5, temos que a média, em D.O., das diluições dos antissoros utilizados em placa de ELISA sensibilizada com TMV e ToMV foi de 0,157 e 0,189, respectivamente, apresentando assim, uma reação cruzada de $83 \%$ aproximadamente, o que é bastante alta e insuficiente para que se possa fazer uma distinção destes vírus através de antissoro policlonal de coelho. 


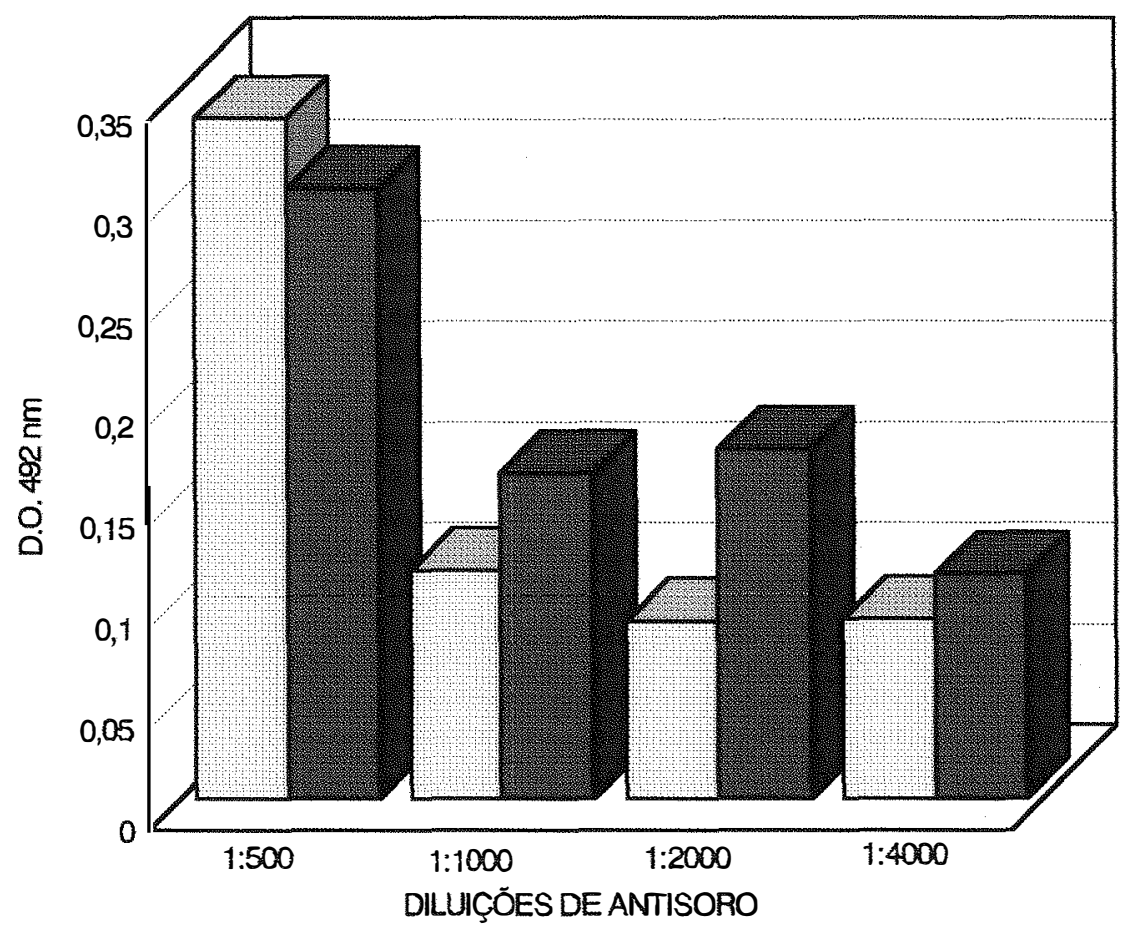

Figura 5 - Resultados obtidos em D.O. a $492 \mathrm{~nm}$, do antissoro policlonal de coelho obtido após a última imunização, testado em placas de ELISA sensibilizadas com TMV e ToMV. 
Outra utilização deste antissoro policlonal de coelho foi na realização do ensaio imunoenzimático quantitativo, discutido mais a frente, onde a utilização de um soro policlonal no Sanduiche Duplo de ELISA é recomendado por diminuir a reação inespecífica que o vírus apresenta com o anticorpo monoclonal, aliando a vantagem de se trabalhar com antissoros oriundos de animais diferentes ( VAN REGENMORTEL \& BURCKARD, 1980).

\section{5 - Ensaio dos anticorpos de coelho anti-ToMV acoplados} com Biotina e Peroxidase

Este ensaio de marcação de antissoros foi realizado com os soros de coelho obtidos contra o ToMV a fim de testar a metodologia, utilizando um antissoro existente em grande quantidade, no caso, o de coelho. Uma vez determinado o melhor método de marcação para o antissoro de coelho, este resultado pode ser utilizado como um modelo para a marcação dos anticorpos monoclonais, evitando assim que se perca material na realização destes testes.

Os antissoros de coelho marcados com Biotina e com Peroxidase foram testados contra os vírus TMV e ToMV em teste de ELISA, realizado com $1 \mu \mathrm{g} / \mathrm{ml}$ dos antígenos para sensibilização das placas de 96 orifícios, utilizando os anticorpos marcados diluídos em tampão PBS na 
concentração de 1:1000, para ambos os anticorpos. Os resultados estão expressos na tabela 4 .

Tabela 4 - Resultado de D.O. a $492 \mathrm{~nm}$, dos soros policlonais de coelho marcados com biotina e com peroxidase, testados em ELISA sensibilizado com TMV e com ToMV, utilizando diferentes diluições dos antissoros de coelho não marcados, onde PERO refere-se aos antissoros marcados com peroxidase e BIOT, aos antissoros marcados com biotina. NORMAL refere-se ao soro de coelho não imunizado.

\begin{tabular}{lllllll}
\hline & & \multicolumn{2}{c}{ TOMV } & \multicolumn{2}{c}{ TMV } \\
\cline { 3 - 6 } DILUIÇÃO & NORMAL & PERO & BIOT & PERO & BIOT \\
\hline 1:100 & 0,007 & 0,416 & 0,141 & 0,202 & 0,081 \\
$1: 200$ & 0,006 & 0,081 & 0,041 & 0,096 & 0,032 \\
$1: 400$ & 0,005 & 0,075 & 0,051 & 0,062 & 0,032 \\
$1: 800$ & 0,005 & 0,081 & 0,032 & 0,047 & 0,031 \\
$1: 1600$ & 0,004 & 0,026 & 0,033 & 0,022 & 0,027 \\
\hline
\end{tabular}


Embora a maioria dos autores trabalhem com marcação de soros com a enzima fosfatase alcalina ( JORDAN et al., 1989; CULVER \& SHERWOOD, 1988; PERMAR \& GOTTWALD, 1989), alguns autores utilizaram com sucesso a marcação de anticorpos com biotina, o que apresenta a vantagem de ser bastante simples de se fazer. Neste caso, a marcação com peroxidase apresentou melhores resultados, como demonstrado por AVRAMEAS et al. (1978), onde o método de marcação com peroxidase mostrou maior eficiência para soros produzidos em coelhos e hamsters, quando em ensaios do tipo ELISA.

GEYSEN et al. (1985) também utilizaram com sucesso a marcação de anticorpos com peroxidase, obtidos a partir de pequenos peptídeos sintetizados correspondentes a epitopos do vírus da aftosa (FMDV), o que mostra também que a marcação de anticorpos mais específicos pode ser realizada utilizando peroxidase.

Para o vírus $M$ da batata, JÄRVEKÜLG et al. (1989) utilizaram a marcação com peroxidase nos soros policlonais obtidos de coelho, porém utilizando um outro método para realizar a marcação. Mc LAUGHLIN et al. (1989) marcaram também anticorpos monoclonais com peroxidase, mas obtidos contra a bactéria Erwinia amilovora, causadora da queima das rosáceas. Todos estes trabalhos consideram a marcação com peroxidase ideal para os patógenos respectivos, comparados com outros marcadores. 


\section{6 - Titulação dos anticorpos monoclonais}

Das 452 colônias que apresentaram crescimento, foram selecionadas 23 "mães", escolhendo-se arbitrariamente um "corte" de D.O. a $492 \mathrm{~nm}$ de 0,200 , onde todos os orifícios que apresentaram D.O. menor foram excluídos que foram repicadas para placa de 24 orifícios contendo 0,5 $\mathrm{ml}$ de FLM em meio HT $20 \%(1 \mathrm{C} 3,1 \mathrm{E} 7,1 \mathrm{H} 6,3 \mathrm{~A} 8,3 \mathrm{~B} 8,3 \mathrm{~F} 2,3 \mathrm{G} 7,4 \mathrm{C} 1$, $8 \mathrm{~A} 6,8 \mathrm{C} 12,8 \mathrm{D} 10,8 \mathrm{G} 6,8 \mathrm{G} 7,9 \mathrm{~B} 10,9 \mathrm{C} 5,9 \mathrm{D} 3,9 \mathrm{H} 2,9 \mathrm{H} 9,9 \mathrm{H} 12,10 \mathrm{E} 5,10 \mathrm{E} 6$, $10 \mathrm{H} 1$ e 10H9 - o primeiro número mostra de que placa de fusão a colônia vem, a letra seguida do segundo número, significa a posição da colônia na placa de fusão).

Ao chegarem ao estágio de semi-confluência, estes hibridomas foram submetidos a um novo teste de ELISA e 10 "mães" foram selecionadas para clonagem ( as colônias 3F12, 8A6, 8C2, 8C12, 8D10, 8G6, 8G7, 9B10, 10H1 e 10H9). Todas as mães foram cultivadas em garrafas de $25 \mathrm{~cm}^{2}$ e congeladas em alíquotas de $2 \times 10^{6}$ células por $\mathrm{ml}$ em meio de congelamento, acondicionadas em "freezer" $-70^{\circ} \mathrm{C}$ e posteriormente em nitrogênio líquido.

Após a reclonagem das mães, das 10 placas de clonagem, 12 clones aparentemente monoclonais e apresentaram resultados positivos em teste de ELISA. Foram eles: 10H9E2, 8C12A2, 10H9F12, 10H9F9, 8C2B2, 8G7G2, 10H9E12, 8C2F5, 8C2H12, 8G7H12, 8C2H12 e 8C2F12 . 
Destes, os clones 8G7G2, 10H9F9, 8C12H12,8C2F5 e 8G7H12 foram multiplicados e passados para produção de ascite em camundongos previamente inoculados com óleo mineral Pristane. Após cerca de 10 dias, o líquido ascítico foi retirado dos camundongos e centrifugado a $2000 \mathrm{~g}$ por 6 minutos. O preciptado dos tubos onde as células se encontravam, foi passado para garrafas de cultura de $25 \mathrm{~cm}^{2}$, contendo 5 $\mathrm{ml}$ de meio R10.

Passados outros 10 dias, observamos ótimo crescimento dos clones $8 \mathrm{G} 7 \mathrm{G} 2,10 \mathrm{H} 9 \mathrm{~F} 9,8 \mathrm{C} 2 \mathrm{~F} 12$ e $8 \mathrm{C} 12 \mathrm{H} 12$. Estes clones foram expandidos para garrafas de cultura de $75 \mathrm{~cm}^{2}$ e após 7 a 10 dias, as colônias apresentavam-se semi-confuentes e o sobrenadante foi recolhido para realização de um teste de ELISA, apresentado Figura 6.

O número reduzido de anticorpos bons obtidos mostra claramente que há a necessidade de realizarmos mais uma fusão de hibridoma, embora para um trabalho pioneiro na área, estes quatro clones são um indicativo de que a aplicabilidade da técnica é bastante promissora para a área fitopatológica. 


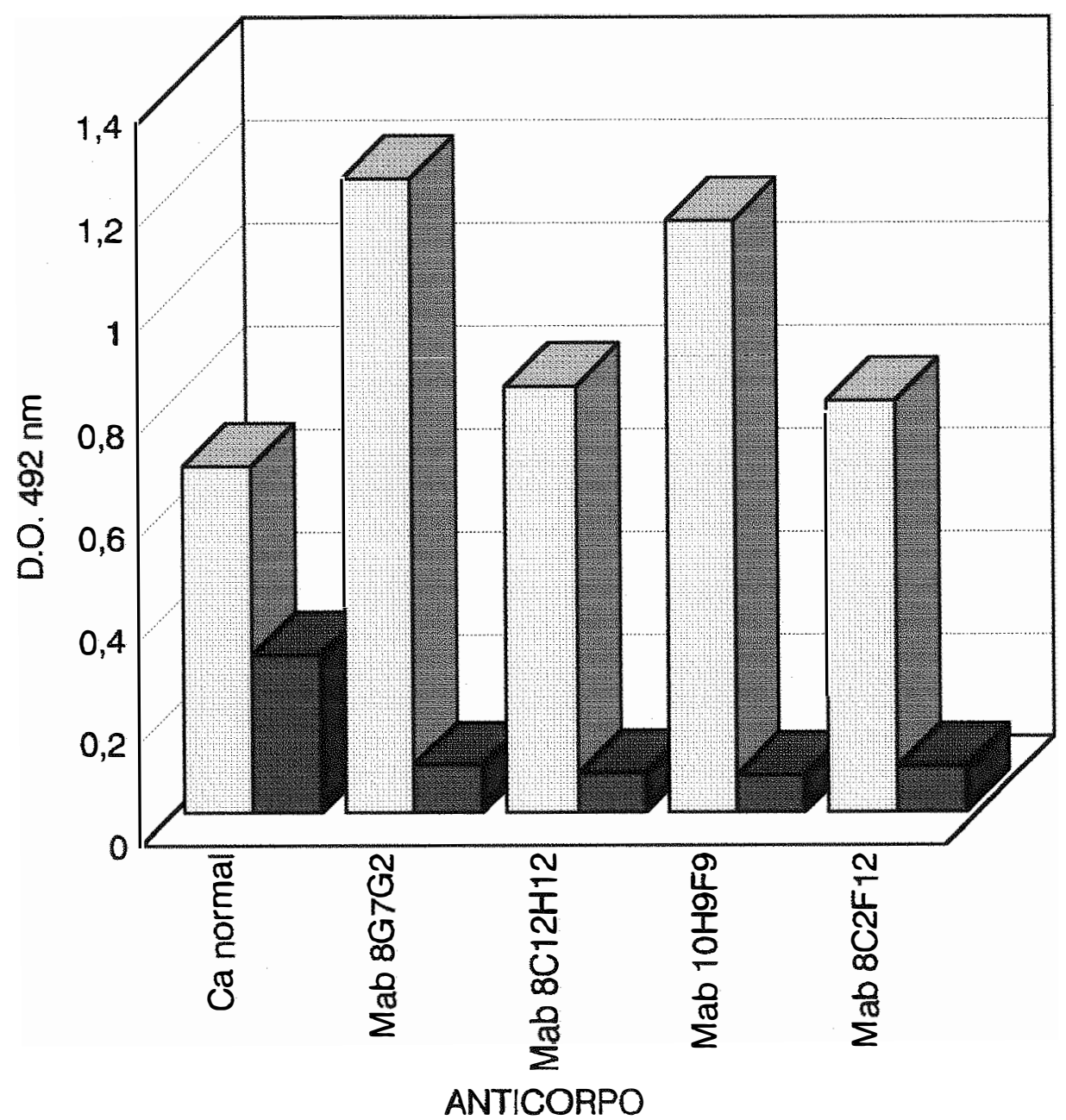

$\square$ TOMV
घTMV

Figura 6 - Gráfico de D.O. a $492 \mathrm{~nm}$, dos anticorpos monoclonais selecionados, em ELISA sensibilizado com ToMV e com TMV. 


\section{7 - Ensaio imunoquantitativo}

Com a finalidade de se determinar quantitativamente os anticorpos testados em ELISA (SCHECHTER \& LOPES, 1990), foi realizado um ensaio de sanduiche duplo de ELISA utilizando o soro policlonal de coelho para a sensibilização da placa, o ToMV, utilizado em quantidades variadas e, depois fazendo-se a ligação com os quatro anticorpos e posterior revelação. Com os resultados obtidos, foi possível estabelecer uma curva quantitativa de ligação específica entre os anticorpos monoclonais e o vírus ToMV.

Nas quantidades estabelecidas de soro policlonal de coelho e do vírus, foi obtida uma curva para o anticorpo monoclonal $867 G 2$ e, embora de forma não tão acentuada, também para o anticorpo $8 \mathrm{C} 12 \mathrm{H} 12$ (Figura 7). Segundo VAN REGENMORTEL \& BURCKARD (1980) com este tipo de teste ( sanduiche duplo de ELISA) pode-se detectar linhagens muito semelhantes ao TMV, utilizando conjugados anti-coelho. 


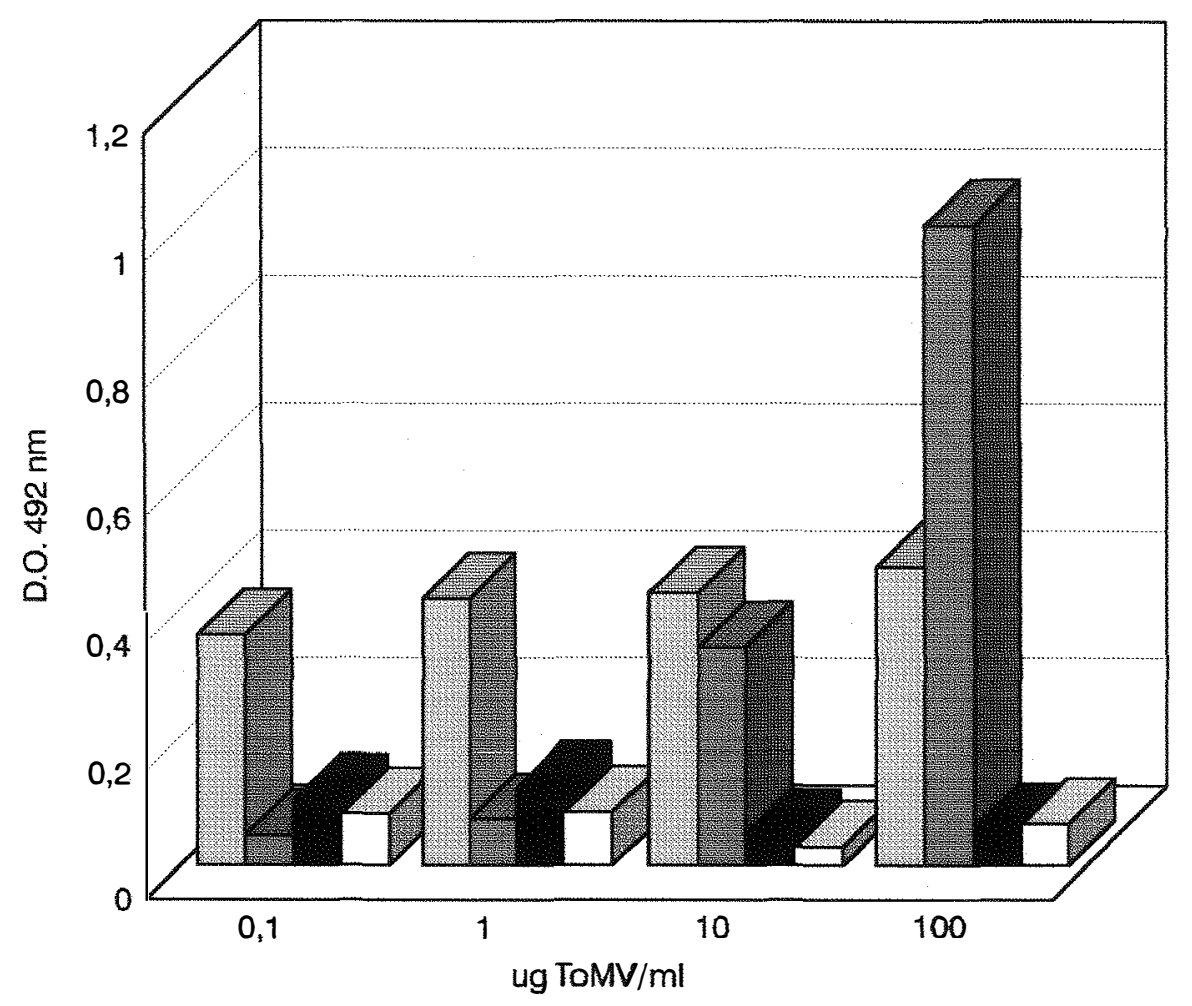

$$
\begin{aligned}
& \square 8 \mathrm{C} 2 \mathrm{~F} 12 \\
& 8 \mathrm{G} 7 \mathrm{G} 2 \\
& 10 \mathrm{H} 9 \mathrm{F9} \\
& \square 8 \mathrm{C} 12 \mathrm{H} 12
\end{aligned}
$$

Figura 7 - Gráfico dos resultados obtidos em D.O. a $492 \mathrm{~nm}$, no ensaio de quantificação (Sanduiche duplo de ELISA, utilizando soro policlonal de coelho anti-ToMV - ToMV - anticorpo monoclonal - conjugado marcado com Peroxidase). 
SHERWOOD et al. (1987) obtiveram também bons resultados de ligação específica em ensaios quantitativos de sanduiche duplo de ELISA, para o PMV ("peanut mottle virus") com anti-PMV obtido de soro policlonal de coelho e com anticorpos monoclonais anti-PMV. Segundo estes mesmos autores, além de se estabelecer uma curva para detecção do vírus, elimina-se os sítios de reação inespecífica, que se ligam no soro policlonal de coelho.

\section{8 - Isotipagem dos anticorpos monoclonais}

A isotipagem foi realizada com os quatro anticorpos monoclonais ( $50 \mu$ l/orifício de sobrenadante de cultura) e foram testadas as 6 imunoglobulinas - $\lg G 1, \lg G 2 a, \lg G 2 b, \lg G 3, \lg M$ e $\lg A$, mais os dois tipos de cadeia leve, Kappa e Lambda.

De acordo com os resultados obtidos, somente o clone 8G7G2 pôde ser caracterizado, pois os outros três clones reagiram inespecificamente contra todos os isotipos testados ( Tabela 5). Este "kit" tem sido utilizado por diversos autores, com a vantagem de ser bastante rápido, fácil e podendo ser testados vários anticorpos monoclonais de uma só vez. CLARK et al. (1989) utilizaram este mesmo "kit" para isotipagem de anticorpos monoclonais contra micoplasma causador de amarelos em aster e 
também obtiveram anticorpos pertencentes à sub-classe lgG e com cadeia leve do tipo Kappa, da mesma forma que OLSEN et al. (1994) para a caracterização de anticorpos monoclonais contra linhagens de Rhizobium. 
Tabela 5 - Resultados em D.O a $405 \mathrm{~nm}$, do teste de isotipagem, com os quatro anticorpos monoclonais, utilizando o "Kit Immuno Select".

\begin{tabular}{|c|c|c|c|c|c|c|}
\hline ISOTIPO & $\begin{array}{c}\text { C. } \\
\text { NEGATIVO }\end{array}$ & $\begin{array}{c}\text { C. } \\
\text { Positivo }\end{array}$ & $8 G 7 G 2$ & $8 \mathrm{C} 2 \mathrm{~F} 12$ & $8 \mathrm{C} 12 \mathrm{H} 12$ & $10 \mathrm{H} 9 \mathrm{Fg}$ \\
\hline anti & & & & & & \\
\hline $\begin{array}{c}\text { mouse } \\
\text { lgG1 } \\
\text { anti }\end{array}$ & 0,177 & 0,913 & 0,114 & 0,603 & 0,129 & 0,287 \\
\hline $\begin{array}{c}\text { mouse } \\
\text { IgG2a } \\
\text { anti }\end{array}$ & 0,098 & 1,541 & 0,101 & 1,194 & 0,104 & 0,266 \\
\hline $\begin{array}{c}\text { mouse } \\
\text { IgG2b } \\
\text { anti }\end{array}$ & 0,088 & 1,472 & 2,413 & 0,699 & 0,102 & 0,419 \\
\hline $\begin{array}{c}\text { mouse } \\
\text { lgG3 } \\
\text { anti }\end{array}$ & 0,097 & 0,531 & 0,089 & 0,766 & 0,099 & 0,601 \\
\hline $\begin{array}{c}\text { mouse } \\
\operatorname{lgM} \\
\text { anti }\end{array}$ & 0,122 & 0,913 & 0,122 & 1,088 & 0,158 & 0,591 \\
\hline $\begin{array}{c}\text { mouse } \\
\text { lgA } \\
\text { anti }\end{array}$ & 0,116 & 0,815 & 0,122 & 0,716 & 0,146 & 0,352 \\
\hline $\begin{array}{c}\text { mouse } \\
\text { Kappa } \\
\text { anti }\end{array}$ & 0,111 & 1,923 & 0,911 & 1,619 & 0,216 & 0,594 \\
\hline $\begin{array}{l}\text { mouse } \\
\text { Lambda }\end{array}$ & 0,089 & 1,435 & 0,094 & 0,273 & 0,249 & 0,446 \\
\hline
\end{tabular}


Na Figura 8, cada anticorpo foi colocado com os controles positivo e negativo do "kit" de isotipagem, de modo a facilitar a análise dos dados obtidos.

O anticorpo monoclonal 8G7G2 apresentou imunoglobulinas do tipo IgG2b, bastante comum para este tipo de imunização e reagiu positivamente com o anti mouse Kappa (Figura 8-A) o que já era esperado, pois este tipo de cadeia leve é bastante comum em camundongos (ROITT et al., 1992). HÜBNER et al. (1992) obtiveram os mesmos resultados com anticorpos monoclonais contra antígenos da família Enterobacteriaceae, para determinação de contaminantes em água potável.

$\mathrm{Na}$ Figura 8-B, vemos que o clone $8 \mathrm{C} 2 \mathrm{~F} 12$ embora apresente um título um pouco mais alto para os isotipos $\lg M$ e $\lg G 3$, comparado com o controle positivo, os títulos para lgG2a e IgA apresentam-se bastante próximos do controle positivo, ficando assim impossível dizer a que classe de imunoglobulinas este anticorpo pertence.

Da mesma forma, nas Figuras 8-C e 8-D, não há diferenças sufucientes para se poder caracterizar estes anticorpos.

Baseado nestes dados, pode-se concluir que os anticorpos $8 \mathrm{C} 2 \mathrm{~F} 12,8 \mathrm{C} 12 \mathrm{H} 12$ e $10 \mathrm{H} 9 \mathrm{~F} 9$ não estão totalmente monoclonais, necessitando uma segunda clonagem para então poderem ser classificados numa só sub-classe de imunoglobulina. 

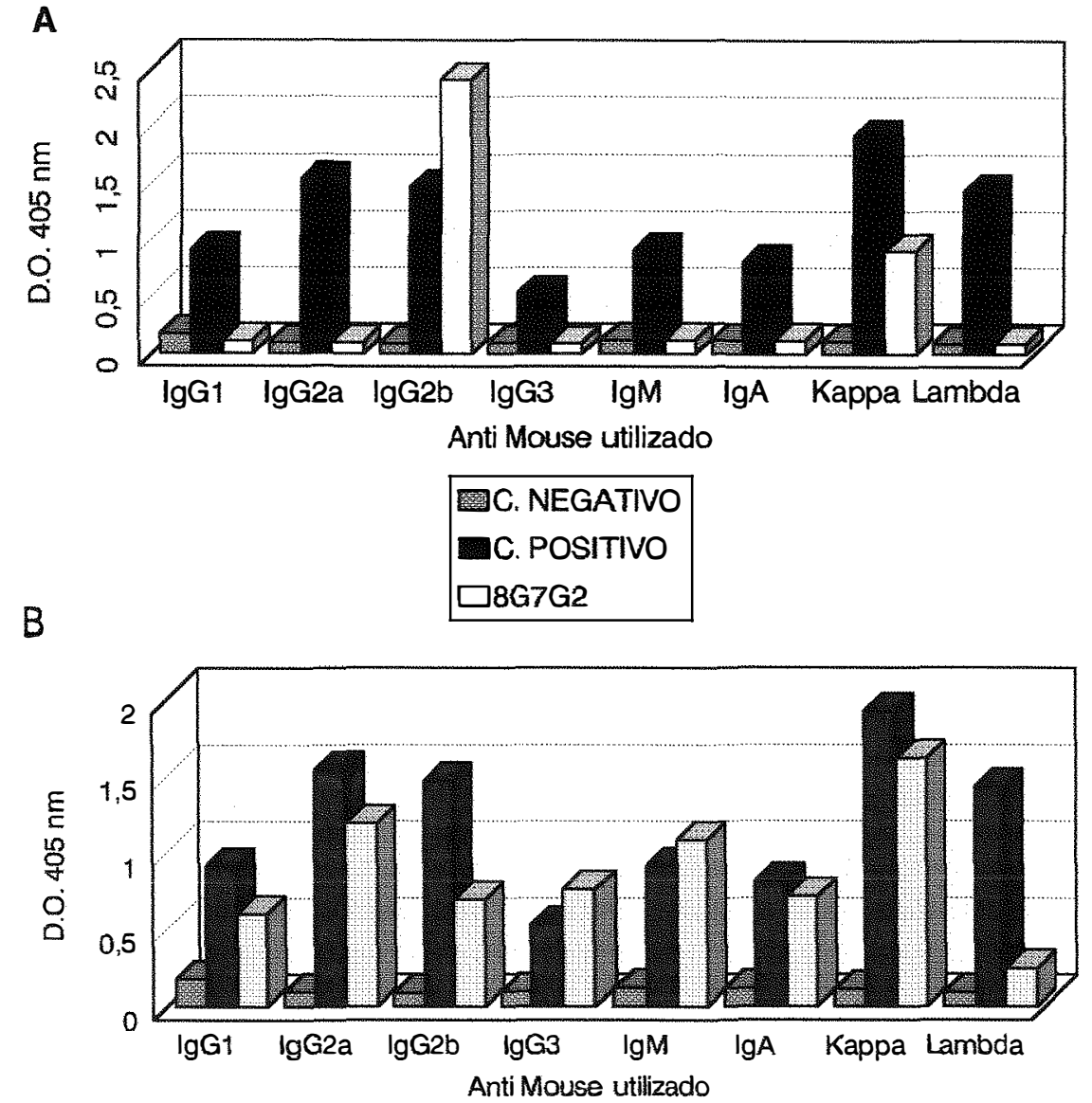

國C. NEGATNO

C. POSITIVO

$\square 8 \mathrm{C} 2 \mathrm{~F} 12$

Figura 8 - Resultados da isotipagem dos anticorpos 8G7G2 (A), 8C2F12

(B), comparados com os controles positivo e negativo do "kit" utilizado. 


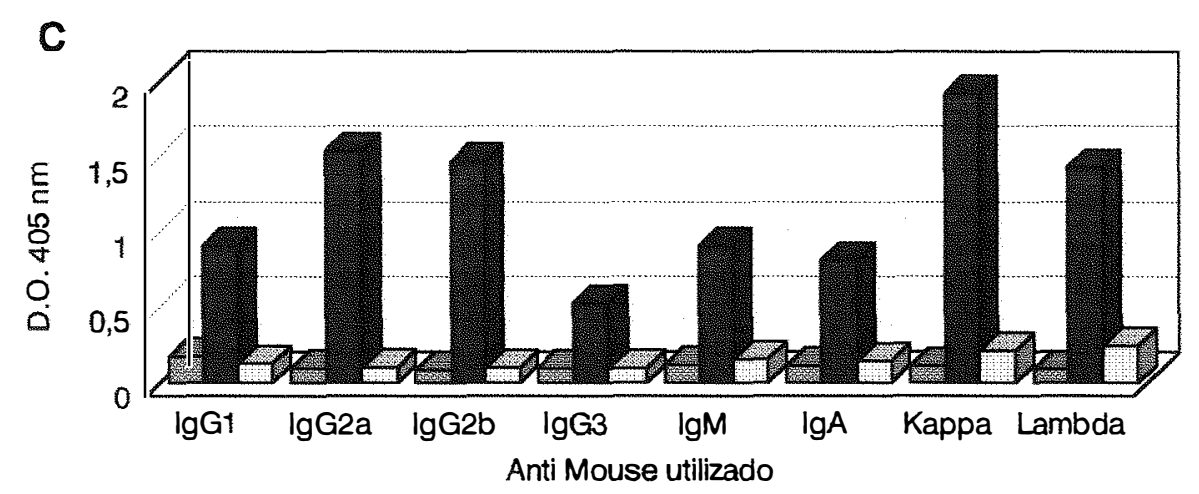

圆C. NEGATIVO

C. POSITIVO

$\square 8 \mathrm{C} 12 \mathrm{H} 12$

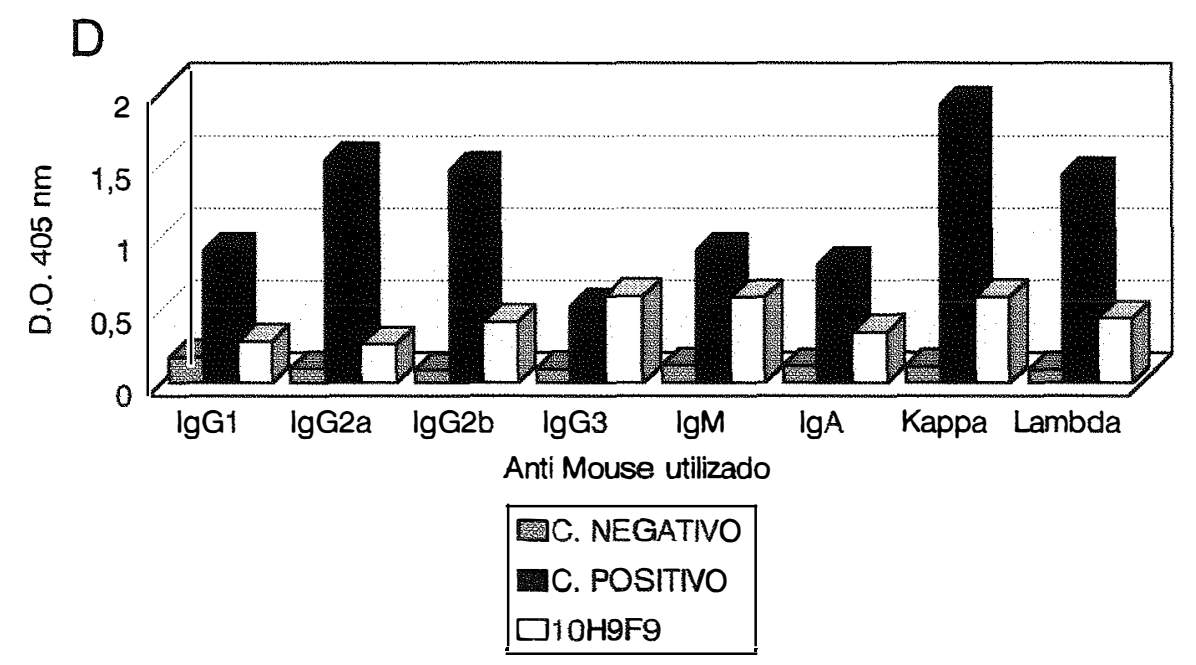

Figura 9 - Resultados da isotipagem dos anticorpos 8C12H12 (C) e 10H9F9

(D) comparados com os controles positivo e negativo do "kit" utilizado. 


\section{5 - CONCLUSÕES}

- Foram produzidos anticorpos monoclonais específicos contra o ToMV e que não apresentam reação cruzada com o TMV.

- Um dos clones ( $8 G 7 G 2$ ) produz anticorpo identificado como uma imunoglobulina da classe IgG2b.

- Os dados sugerem que o intervalo entre imunizações com o ToMV pode ser de 30 dias.

- O pequeno número de anticorpos monoclonais obtidos indica a necessidade de obtenção de novos hibridomas. 


\section{REFERÊNCIAS BIBLIOGRÁFICAS}

AL MOUdALLAL, Z.; ALSCHUH, D.; BRIAND, J. P.; VAN REGENMORTEL, M. H. V. Comparative sensitivity of different ELISA procedures for detecting monoclonal antibodies. Journal of Immunological Methods, Amsterdam, 68 : 35-43, 1984.

ANDERSON, N. G. High-resolution protein separation and identification methods applicable to virology. Current Topics in Microbiology and Immunology, Berlin, 104: 197-217, 1983.

AVRAMEAS, S. Coupling of enzymes to proteins with glutaraldehyde. Immunochemistry, Oxford ,6: 43-52, 1969.

AVRAMEAS, S. T.; TERNYNCK, T.; GUESDON, J. L. Coupling of enzymes to antibody and antigens. Scandinavian Journal of Immunology, Oxford, 7: 7-23, 1978.

BAHRANI, Z.; SHERWOOD, J. L.; SANBORN, M. R.; KEYSER, G. C. The use of monoclonal antibodies to detect wheat soil-borne mosaic virus. Journal of General Virology, London, 69: 1317-22, 1988.

BARNA-VETRÓ, I.; GYÖNGYÖSI, A.; SOLTI, L. Monoclonal antibody-based enzyme-linked immunosorbent assay of Fusarium T-2 and Zearalenone toxins in cereals. Applied and Environmental Microbiology, Washington , 60 (2): $729-31,1994$. 
BASTIN, J. M.; KIRKLEY, J;; MC MICHAEL, A. J. Production of monoclonal antibodies: a pratical guide. In: MC MICHAEL, A. J. \& FABRE, J. Monoclonal antibodies in clinical medicine.London, Academic Press, 1982. cap. 21, 505 -17.

BERGAMIN FILHO, A. Vírus. In: GALLI, F. ed. Manual de fitopatologia. 2. ed., São Paulo, Agronômica Ceres, 1978. v.1, p.141-9.

BHUNIA, A. K. \& JOHNSON, M. G. Monoclonal antibody-colony immunoblot method specific for isolation of Pediococcus acidilactici from foods and correlation with pediocin (bactiricin) production. Applied and Envirionmental Microbiology, Washington ,58(7): 2315-20, 1992.

BOS, L. Introduction to plant virology. London, Longman, 1983. 160p.

BRADFORD, M.M. A rapid and sensitive method for the quantification of microgram quantities of protein utilizing the principle of protein-dye binding. Analitical Biochemistry, San Diego, 72: 248-254, 1978.

BREUIL, C.; LUCK, B. T.; ROSSIGNOL, L.; LITTLE, J.; ECHEVERRI, C. J.; BANERJEE, S.; BROWN, D. L. Monoclonal antibodies to Gliocladium roseum, a potencial biological control fungus of sap-staning fungi in wood. Journal of General Microbiology, London, 138: 2311-9, 1992.

CAMPBELL, A. M. Monoclonal Antibody technology: the production and characterization of rodent and human hibridomas. In: BURDON, R. $H$. \& KNIPPENBERG, P. $H$. van. Laboratory techniques in biochemistry and molecular biology. Amsterdam, Elsevier, 1984. v. $13,231 p$.

CANER, J.; COLARICCIO, A.; CHAGAS, C.M.; ALBA, A.P.C.; VICENTE, M. Identificação de um isolado do vírus do mosaico do tomateiro 
(ToMV) no estado de São Paulo. Fitopatologia Brasileira, Brasília, 15(4): 347-50, 1990.

CHEN, T. A. \& JIANG, X.F. Monoclonal antibodies against maize bushy stunt agent. Canadian Journal of Microbiology, Ottawa, 34: 6-11, 1988.

CLARK, M. F. \& ADAMS, A. N.. Characteristics of the microplate method of Enzyme-Linked Immunosorbent Assay for detection of plant viruses. Journal of General Virology, London, 34 : 475-83, 1977.

CLARK, M.F.; MORTON, A.; BUSS, S.L. Preparation of micoplasma immunogens from plants and a comparison of polyclonal and monoclonal antibodies made against primula yellows MLO associated antigens. Annals of Applied Biology, Cambridge,114: 111-4, 1989.

CULVER, J. N. \& SHERWOOD, J. L. Detection of peanut stripe virus in peanut seed by an indirect Enzyme-Linked Immunosorbent Assay using a monoclonal antibody. Plant Disease, Washington, 72(8) : 676-9, 1988.

DE BOER, S. H.; WUCZOREK, A.; KUMMER, A. An ELISA test for bacterial ring rot of potato with a new monoclonal antibody. Plant Disease, Washington, $72: 874-8,1988$.

DIETZGEN, R. G. \& SANDER, E. Monoclonal antibodies against a plant virus. Archives of Virology, Wien, 74: 197-204, 1982.

FERNANDES, J. J.; CARVALHO, M. G.; ALMEIDA, E. G. Distribuição do mosaico em tomatais de duas regiões produtoras de Minas Gerais. Fitopatologia Brasileira, Brasília , 8: 625, 1983. 
GEORGE, R. A. \& CONVERSE, R. H. Methods for enrichiment of desired B-cell populatios before anti-cauliflower mosaic virus hybridoma formation. Phytopathology, Lancaster, 72: 1631-6, 1988.

GERHARD, W.; CROCE, C. M.; LOPES, D.; KOPROWSKI, H. Repertoire of antiviral antibodies expressed by somatic cell hybrids. Proceedings of the National Academy of Science od United States of America, Washington, 75: 1510-4, 1978.

GEYSEN, H. M.; BARTELING, S. J.; MELOEN, R. H. Small peptides induce antibodies with a sequence and structural requirement for binding antigen comparable to antibodies raised against the native protein. Proceedings of the National Academy of Science od United States of America, Washington, 82: 178-82, 1985.

GODING, J. W. Monoclonal antibodies: principles and practice. 2 . ed. London, Academic Press, 1986. 315 p.

HALK, E. L. \& DE BOER, S. Monoclonal antibodies in plant-disease research. Annual Review of Phytopathology, Palo Alto, 23: 321-50, 1985.

HALK, E. L.; HSU, H. T.; AEBIG, J.; FRANKE, J. Production of monoclonal antibodies against three ilarviruses and alfafa mosaic virus and their use in serotyping. Phytopathology ${ }_{2}$ Lancaster, 74 (3): 367-72, 1984.

HASTINGS, K. L.; TULIS, J. J.; DEAN, J. H. Production and characterization of a monoclonal antibody to aflatoxin. Journal of Agriculture and Food Chemestry, Easton, 36: 404-8, 1988.

HATAYA, T.; INOUE, A. K.; OHHSHIMA, K.; SHIKATA, E. Characterization and strain identification of a potato virus $Y$ isolate non-reactive with monoclonal antibodies specific to ordinary and necrotic strains. Intervirology, Basel, 37: 12-9, 1994. 
HOLLINGS, M. \& HUTINGA, H. Tomato mosaic virus. C.M.I.IA.A.B. Descriptions of Plant Viruses. No. 156. 1976.

HÜBNER, I.; STEINMETZ, I.; OBST, U.; GIEBEL, D.; BITTER-SUERMANN, D. Rapid determination of members of the family Enterobacteriaceae in drinking water by an immunological assay using a monoclonal antibody agaisnt enterobacterial common antigen. Applied and Environmental Microbiology, Washington, 58(9): 3187-91, 1992.

HURN, B. A. L. \& CHANTLER, S. M. Production of reagent antibodies. Methods in Enzymology, New York, 70:104-42, 1980.

JÄRVEKÜLG, L.; SÕBER, J.; SINIJÄRV, R.; TOOTS, I.; SAARMA, M. Time-resolved fluoroimmunoassay of potato virus $M$ with monoclonal antibody. Annals of Applied Biology, Cambridge, 114: 279-91, 1989.

JONES, A. T.; MITCHELL, M. J.; BROWN, J. F. Infectibility of some new raspberry cultivars with arabic mosaic and raspberry ringspot viruses and further evidence for variation in British isolates of these two nepoviruses. Annals of Applied Biology, Cambridge, 115: 57-69, 1989.

JONES, J. B. ; STALL, R. E.; ZITTER, T. A. Compendium of tomato diseases . St. Paul, APS Press, 1991. 75p.

JONES, E. Monoclonal antibody technology. In: MURREL, J. C. \& ROBERTS, L. M. Understanding genetic engineering, Chichester, Ellis Horwood, 1989. cap. 8, p.101-10.

JORDAN, R. L.; KONAI, M.; LEE, I. M.; DAVIS, R. E. Species-specific and cross-reactive monoclonal antibody to the plant pathogenic Spiroplasma citri and S. kunkelii. Phytopathology, Lancaster, 79: 880-7, 1989. 
KAWAI, A.; KOBAYASHI, Y.; TSUKAMOTO, T; DAI, K; KIMURA, S.; GOTO, M. Production of monoclonal antibodies against citrus tatter leaf virus. Research Bulletin of the Plant Protection Service, Yokohama, 27: 55-6, 1991.

KEARNEY, J. F. ; RADBRUCH, A. ; LIESEGANG, B.; RAJENSKY, K. A new mouse myeloma cell line that lost immunoglobulin expression but permits the construction of antibody secreting hybrid cell lines. Journal of Immunology, Baltimore, 123: 1548-50, 1979.

KITAJIMA, E. W. Novas abordagens na diagnose de doenças incitadas por fitoviroses. Fitopatologia Brasileira, Brasília, 16 (2): 4, 1991.

KOLLER, G. \& MILSTEIN, C. Continuous cultures of fused cells secreting antibody of pre-defined specificity. Nature, London, 256: 495-7, 1975.

KOPROWSKI, $H_{\text {.; }}$ GERHARD, W.; CROCE, C.M. Production of antibodies against influenza virus by somatic cell hybrids between mouse mieloma and primed spleen cells. Proceedings of the National Academy of Science od United States of America, Washington, 74: 2985-8, 1977.

LOPES, J. D.; CARNEIRO, C. R. W. ; VILELA, A. A.; CAMARGO, E. P. Production of monoclonal antibodies against Schistosoma mansoni and trypanosomatid : a methodologycal report. Revista do Instituto de Medicina Tropical ,São Paulo, 24: 327-36, 1992.

MARKHAM, R. The biochemistry of plant viruses. In: BURNET, F. M. \& STANLEY, W. M., ed. The viruses: biochemical, biological and biophysical properties. New York, Academic Press, 1959. vol.2, p. 33-119.

Mc CULLOUGH, K. C. Monoclonal antibodies: implications for virology. Archives of Virology, Wien ,87: 1 -36, 1986. 
Mc LAUGHLIN, R. J.; CHIEN, T. A.; WELLS, J. M. Monoclonal antibodies against Erwinia amylovora: characterization and evaluation of a mixture for detection by Enzyme-Linked Immunosorbent Assay. Phytopathology, Lancaster, 79: 610-3, 1989.

OI, V. T. \& HERZENBERG, L. A. Antibody purification: protein A-sepharose column chromatography. In: MISHELL, B.B. \& SHIIGI, S. M. Selected methods in cellular immunology. San Francisco, Freeman, 1980. p. 368-70.

OLSEN, P.; WRIGHT, S.; COLLINS, M.; RICE, W. Patterns of reactivity between a panel of monoclonal antibodies and forage Rhizobium strains. Applied and Environmental Microbiology, Washington, 60 (2): $654-61,1994$.

PASQUINI, G. \& BARBA, M. Production and aplication of monoclonal antibodies against apple mosaic virus. Petria, Roma, 1(1): 31-6, 1991.

PERMAR, T. A. \& GOTTWALD, T. R. Specific recognition of a Xanthomonas campestris Florida citrus nursery strain by a monoclonal antibody probe in a microfiltration enzyme immunoassay Phytopathology, Lancaster, 79: 780-3, 1989.

ROITT, I. M.; BROSTOFF, J.; MALE, D. K. Imunologia. 2. ed., São Paulo, Manole, 1992. p. irreg.

SCHECHTER, G. B. \& LOPES, J. D. Two-site immunoassays for the measurament of serum laminin: correlation with breast cancer staging and presence of auto-antibodies. Brazilian Journal of Medical and Biological Research, Brasília, 23: 141-9, 1990. 
SEQUEIRA, J. C. Técnicas serológicas e bio-moleculares de diagnóstico de vírus e viróides em plantas. Summa Phytopathologica, Jaguariúna, 18 (2): 79-110, 1992.

SHERWOOD, J. L.; SANBORN, M. R.; KEYSER, G. C. Production of monoclonal antibodies to peanut mottle virus and their use in enzime-linked immunosorbent assay and dot-immunobinding assay. Phytopathology, Lancaster, 77 (8): 1158-61, 1987.

SHERWOOD, J. L.; SANBORN, M. R.; KEYSER, G. C.; MYERS, L. D. Use of monoclonal antibodies in detection of tomato spotted wilt virus. Phytopathology, Lancaster, 79 (1): 61-4, 1989.

SHULMAN, M.; WILDE, C. D.; KOHLER, G. A better line for making hybridomas secreting specific antibodies. Nature, London, 276: 269-70, 1985.

ST. GROTH, S. F.de \& SCHEIDEGGER, D. Production of monoclonal antibodies: strategies and tatics. Journal of Immunology Methods, Amsterdam, 35: 1-21, 1980.

TORRANCE, L.; PEAD, M. T.; BUXTON, G. Production and some characteristics of a monoclonal antobody against beet necrotic yellow vein virus. Annals of Applied Biology, Cambridge, 113: 519-30, 1988.

VAN REGENMORTEL, M. H. V. Serology and immunochemistry of plant viruses. New York, Academic Press, 1982. 302p.

VAN REGENMORTEL, M. H. V. \& BURCKARD, J. Detection of a wide spectrum of tobacco mosaic virus strains by indirect enzyme-linked immunosorbent assays (ELISA). Virology, San Diego,106: 327 34, 1980. 
VAN REGENMORTEL, M. H. V. \& LEGARGE, N. The antigenic specificity of different states of agregation of tobacco mosaic virus protein. Virology, San Diego, 52: 89-104, 1973.

VOLLER, A.; BARTLETT, A.; BIDWELL, D. E.; CLARK, M. F.; ADAMS, A. $\mathrm{N}$. The detection of viruses by Enzyme-Linked Immunosorbent Assay (ELISA). Journal of General Virology, London, 33: 165-7, 1976.

YEWDELL, J. W. \& GERHARD, W. Antigenic characterization of viruses by monoclonal antibodies. Annual Review of Microbiology, Palo Alto, 35: 185-206, 1981.

WARD, B. B.; COCKCROFT, A. R.; KILPATRICK, K. A.. Antibody and DNA probes for detection of nitrite reductase in seawater. Journal of General Microbiology, London, 139: 2285-93, 1993.

WIKTOR, T. J. \& KOPROWSKI, H. Monoclonal antibodies against rabies virus produced by somatic cell hybridization: detection of antigenic variants. Proceedings of the National Academy of Science od United States of America, Washington, 75: 3938-42, 1978.

WOFSY, L. Methods and aplications of Hapten-Sandwuich Labeling. Methods in Enzymology, New York, 92(5): 472 - 88, 1983. 